\title{
The impact of increased flooding occurrence on the mobility of potentially toxic elements in floodplain soil - a review
}

Article

Accepted Version

Creative Commons: Attribution-Noncommercial-No Derivative Works 4.0

Ponting, J., Kelly, T. J., Verhoef, A., Watts, M. J. and Sizmur, T. (2021) The impact of increased flooding occurrence on the mobility of potentially toxic elements in floodplain soil - a review. Science of the Total Environment, 754. 142040. ISSN 0048-9697 doi: https://doi.org/10.1016/j.scitotenv.2020.142040 Available at https://centaur.reading.ac.uk/92613/

It is advisable to refer to the publisher's version if you intend to cite from the work. See Guidance on citing.

To link to this article DOI: http://dx.doi.org/10.1016/j.scitotenv.2020.142040

Publisher: Elsevier

All outputs in CentAUR are protected by Intellectual Property Rights law, including copyright law. Copyright and IPR is retained by the creators or other copyright holders. Terms and conditions for use of this material are defined in the End User Agreement.

www.reading.ac.uk/centaur 
Central Archive at the University of Reading

Reading's research outputs online 
2 The impact of increased flooding occurrence on the

3 mobility of potentially toxic elements in floodplain soil

- A review

5

6 Jessica Ponting ${ }^{a, b}$, Thomas J. Kelly ${ }^{a, c}$, Anne Verhoef ${ }^{a}$, Michael J. Watts ${ }^{b}$ and

7 Tom Sizmur a*

8

9 a Department of Geography and Environmental Science, University of Reading, Reading, RG6

$106 \mathrm{DW}, \mathrm{UK}$

11 b Inorganic Geochemistry, Centre for Environmental Geochemistry, British Geological

12 Survey, Keyworth, Nottingham, NG12 5GG, UK

13

${ }^{c}$ Department of Geography, Queen Mary University of London, Mile End Road, London, E1

14 4NS, UK

15

$16 *$ Corresponding author

17 Department of Geography and Environmental Science

18 Russell Building

19 University of Reading

20 Reading

21 RG6 6DW, UK

22 t.sizmur@reading.ac.uk

23

$+44(0) 1183788913$ 
The frequency and duration of flooding events are increasing due to land-use changes increasing runoff of precipitation, and climate change causing more intense rainfall events. Floodplain soils situated downstream of urban or industrial catchments, which were traditionally considered a sink of potentially toxic elements (PTEs) arriving from the river reach, may now become a source of legacy pollution to the surrounding environment if PTEs are mobilised by unprecedented flooding events.

When a soil floods, the mobility of PTEs can increase or decrease due to the net effect of five key processes; (i) the soil redox potential decreases which can directly alter the speciation, and hence mobility, of redox sensitive PTEs (e.g. Cr, As), (ii) pH increases which usually decreases the mobility of metal cations (e.g. $\mathrm{Cd}^{2+}, \mathrm{Cu}^{2+}, \mathrm{Ni}^{2+}, \mathrm{Pb}^{2+}, \mathrm{Zn}^{2+}$ ), (iii) dissolved organic matter (DOM) increases, which chelates and mobilises PTEs, (iv) Fe and Mn hydroxides undergo reductive dissolution, releasing adsorbed and co-precipitated PTEs, and (v) sulphate is reduced and PTEs are immobilised due to precipitation of metal sulphides. These factors may be independent mechanisms, but they interact with one another to affect the mobility of PTEs, meaning the effect of flooding on PTE mobility is not easy to predict. Many of the processes involved in mobilising PTEs are microbially mediated, temperature dependent and the kinetics are poorly understood.

Soil mineralogy and texture are properties that change spatially and will affect how the mobility of PTEs in a specific soil may be impacted by flooding. As a result, knowledge based on one river catchment may not be particularly useful for predicting the impacts of flooding at another site. This review provides a critical discussion of the mechanisms controlling the mobility of PTEs in floodplain soils. It summarises current understanding, identifies limitations to existing knowledge, and highlights requirements for further research.

Key words; floodplain soil, flooding, climate change, potentially toxic elements, contamination, mobility 


\section{Introduction}

Flooding is a major event that currently affects an estimated 20 to 300 million people per year, and accounts for around $40 \%$ of natural disasters occurring worldwide, threatening both social security and sustainable development (Euripidou and Murray, 2004; Hirabayashi and Kanae, 2009). Alterations to land use and land cover are having widespread implications for catchment characteristics; with soil sealing and impermeable surfaces increasing surface run-off, as well as a reduction of natural buffering environments such as forests and wetlands, meaning there is less capacity to accommodate flood waters in the same river reach (Dadson et al., 2017; Kundzewicz et al., 2014). There is growing evidence, from climate models, that short-term extreme weather events (e.g. high-frequency rainstorms, heat waves and wind storms) are likely to become increasingly frequent in many parts of the world, threatening the long-term functioning of the terrestrial system (Harvey et al., 2019; Kharin et al., 2007; Madsen et al., 2014; Pendergrass, 2018; Stagl et al., 2014). It is likely that populations will experience warmer and drier summers, and an increase in the intensity of heavy rainfall, contributing to more frequent pluvial, fluvial, groundwater or coastal flooding, and resulting in the occasional inundation of land that has rarely been flooded in the past (Barber et al., 2017; Kundzewicz et al., 2014; Schaller et al., 2016). The likelihood of flooding is also determined by antecedent soil moisture conditions. The proportion of soil pore space that is filled with water at any given time is largely dependent on local hydrological processes and stores including; infiltration, surface and sub-surface runoff (when rainfall intensity exceeds infiltration capacity), redistribution and drainage to/from groundwater, evaporation, and transpiration (Stagl et al., 2014). Srivastava et al., 2017; Tóth et al., 2016b). Since many commercial, industrial, residential and agricultural developments have historically been situated adjacent to rivers; they contribute to the contamination of river sediments, and these sediments are often deposited onto the floodplain soils 
al., 2014; Zhao et al., 1999). Here we use the term PTEs, also referred to in the literature as 'trace elements' or 'heavy metals', to encompass all metals, metalloids, non-metals and other inorganic elements in the soil-plant-animal system, of which their mobility and potential toxicity to that system and/or humans is largely dependent upon their concentration, bioavailability and chemical form (Hooda, 2010; Rodgers et al., 2015). The term "mobility" is a concept that has been frequently used to estimate the risk of contamination from the soil to the surrounding environment by PTEs (Domergue and Vedy, 1992). Here we define mobile PTEs as those elements that are dissolved in soil porewater or associated with colloids and thus capable of leaching from the soil profile, or being taken up into plants or soil organisms. The mobility and subsequent fate of PTEs in periodically (occasionally) flooded soils (such as floodplain soils) are imperfectly understood. The legacy of historic contamination and continuing increases in emissions from urban activities pose a serious environmental threat globally (de Souza Machado et al., 2016; Srivastava et al., 2017). Human actions to mitigate and adapt to the impacts of climate change may influence the fate of contaminants, with climate change itself also potentially affecting the toxicity of the contaminants within the environment (Stahl et al., 2013).

The aim of this literature review is to provide an understanding of the factors involved in the mobility of PTEs in soil by pulling together interdisciplinary knowledge in this area. The review will first consider in more detail the expected changes to global rainfall patterns, the implications of these changes for flooding, and the role that floodplains play during inundation, as well as the changes they undergo. The review will then showcase how PTEs have entered the floodplain soil and how flooding influences soil biogeochemical processes which, in turn, influence PTEs mobility, using examples from the literature. Finally, this knowledge is used to identify gaps that will help to make recommendations for future research into the effects of flooding on the mobility and fate of PTEs. 


\subsection{Expected changes to global rainfall patterns and implications for flooding}

Anthropogenic (human) activities including intensified land use; urbanisation, forestry, cultivation, and fossil energy use have increased atmospheric greenhouse gas concentrations which are driving changes in climate and leading to increases in rainfall intensity and surface run-off that are associated with increased flood risk (Bronstert, 2003; Chang and Franczyk, 2008; Kharin et al., 2007; Kundzewicz et al., 2014; Wheater and Evans, 2009). Mean global temperatures have risen by $1.1^{\circ} \mathrm{C}$ since the end of the $19^{\text {th }}$ century; the "Paris Climate Agreement" seeks to contain global mean temperatures well below $2^{\circ} \mathrm{C}$ and, ambitiously, below $1.5^{\circ} \mathrm{C}$ (Alfieri et al., 2017; Bronstert, 2003; Huddart et al., 2020; Mullan et al., 2019). The Intergovernmental Panel on Climate Change (IPCC) has predicted that under the A1B (medium) emissions scenario, temperatures will increase between 1.1 and $6.4^{\circ} \mathrm{C}$ by the year 2100 , leading to an increase in atmospheric water holding capacity and therefore variations to seasonal rainfall (Arnell et al., 2015; Bell et al., 2012; Chan et al., 2014; Clemente et al., 2008; González-Alcaraz and van Gestel, 2015; Jenkins et al., 2009). It has been argued that we will experience an intensification of short-duration heavy rainfall events rather than a uniform increase in the daily average rainfall (Chan et al., 2014; Hirabayashi et al., 2008; Kharin et al., 2007; Kundzewicz et al., 2014).

An IPCC Special Report (SREX) on climate extremes (IPCC, 2012) assessed it is likely there have been statistically significant increases in the number of heavy precipitation events in more regions than significant decreases, with strong regional and sub-regional variation. The observed changes to precipitation extremes have been found to be far less spatially coherent or statistically significant compared with changes found in temperature extremes (Kundzewicz et al., 2014). Projected scenarios with $4^{\circ} \mathrm{C}$ warming showed more than $70 \%$ of the global population will face increased flood risk (Alfieri et al., 2017). Increases in flood frequency are expected in; Europe, America, Southeast Asia, eastern Africa, and Peninsular India. Populations in regions such as Bangladesh, Mumbai and Thailand are potentially at higher risk from flooding due to predicted increases in rainfall, coupled with changes in land use (e.g. irrigation schemes and construction of dams), and increasing population size requiring 
rapid expansion of urban areas (Hirabayashi et al., 2013; Kundzewicz et al., 2014; Tockner et al., 2010). However, climate projections tend to have relatively low levels of model confidence, particularly for the prediction of fluvial floods because there is still relatively limited evidence and the causes of regional changes to flood occurrence are complex (Hirabayashi et al., 2013).

Flooding tends to be heterogeneous as it is affected not only by variability of the climatological and hydrological systems but also by land-use and the effect is has on the storage capacity of the receiving catchment (storage and drainage basin conditions). Changes to the characteristics of precipitation (the frequency, intensity and timing of rainfall) will have decisive implications for flood risk (Bronstert, 2003; Hirabayashi and Kanae, 2009; Kundzewicz et al., 2014). However, pre-existing high river levels and groundwater levels, as well as saturated soils are equally important to establish the capacity of the receiving catchment to cope with further rainfall (Maggioni and Massari, 2018; Wilby et al., 2008). The extent of flooding in a particular catchment will depend largely on the topography (variation in elevation), along with vegetation type, proportion of land used for cultivation and the extent of urbanised areas positioned upstream (Arnell et al., 2015; Bell et al., 2012; Bronstert, 2003; Chang and Franczyk, 2008; Kundzewicz et al., 2014; Qiao et al., 2019). Urbanisation is a global issue; with more than half the world's population now living in cities, the process of urbanisation is leading to greater human occupation of floodplains, often with inadequate drainage planning (Kundzewicz et al., 2014; Pathirana et al., 2014).

The probability of flooding occurring in a particular region is often related to regional processes like El Niño Southern Oscillation (ENSO) cycle and the North Atlantic Oscillation (NAO) that, in turn, cause global impacts. The intensity (frequency and amplitude) of both ENSO and NAO are influenced by other modes of variability, for example; Pacific Decadal Oscillation (PDO) and Interdecadal Pacific Oscillation (IPO) which cause opposite atmospheric and sea surface temperatures and can therefore determine the magnitude of floods (Grimm and Tedeschi, 2009; Johnson et al., 2020). ENSO is a rapid warming of the sea surface temperature (by $1-5{ }^{\circ} \mathrm{C}$ ) of the equatorial Pacific over the duration of a 
few weeks, resulting in extreme rainfall and increased cyclone activity in some regions, and risk of drought and forest fires in others (Berz et al., 2001; Grimm and Tedeschi, 2009; Karl and Trenberth, 2003; Kundzewicz et al., 2014; Tedeschi and Collins, 2016). Periods of extreme rainfall and subsequent flooding have been found to correlate with ENSO events in North and South America as well as in Africa (Berz et al., 2001; Brönnimann, 2007; Kundzewicz et al., 2014). NAO is an atmospheric pattern that affects the severity of winter temperatures and precipitation over Europe and eastern North America (Karl and Trenberth, 2003). Intense rainfall is a common cause of river basin flooding; however, in high latitude regions it is changes in temperatures altering the timing of seasonal snowmelt and causing glacier retreat that commonly causes flooding, for example in north-eastern Europe, Central and South America, and in polar regions such as the Russian Arctic (Blöschl et al., 2017; Hirabayashi et al., 2008; Kharin et al., 2007; Kundzewicz et al., 2014; Stagl et al., 2014). Rising global sea-level $\left(11-16 \mathrm{~cm}\right.$ in the $20^{\text {th }}$ century and a further $0.5 \mathrm{~m}$ predicted this century) will certainly increase risk of flooding caused by tidal processes, with current estimates that 630 million people live on land below projected annual flood levels for 2100 (Kulp and Strauss, 2019). While there is uncertainty regarding the effect that future climate change will have on river levels (Prudhomme and Davies, 2009), changes made to land-use, and land cover, for example by urbanisation, will drive changes in the local climate (at the kilometre scale) influencing the hydrometeorological regime and resulting in more flooding (Foley et al., 2005; Hirabayashi and Kanae, 2009). Pathirana et al. (2014), using a 3D atmospheric model coupled with a land surface model (WRF-ARW) in southern India, found that in three out of four simulated cases there was a significant increase in local extreme rainfall when urbanisation in the area increased. This work was conducted in southern India, however the model could be applied and validated to other regions to establish whether this correlation is found globally.

\subsection{The role of floodplains during floods}

Floodplains are by definition dynamic environments subjected to fluctuations between flooding and drying (Vijver et al., 2007). They are distinctive landscape features, often on low-lying ground, and 
characterised by a high spatio-temporal heterogeneity (Schulz-Zunkel et al., 2015; Stuart and Lapworth, 2011; Tockner et al., 2010; Tockner and Stanford, 2002). Periodic overbank inundation from the adjacent watercourse, overland flow, subsurface flow, and changes to the groundwater levels result in a constantly changing water balance and degree of floodplain saturation (Stuart and Lapworth, 2011; Tockner and Stanford, 2002). Floodplain topography and variations in elevation are usually slight but have an important effect on the degree of soil saturation across the floodplain, depending on the overall water balance from surface and sub-surface run-off (Arnell et al., 2015; Kundzewicz et al., 2014; Qiao et al., 2019). including lateral overflow of rivers or lakes, rising groundwater, upland sources, and direct precipitation. Several different factors and water sources normally contribute to a flooding event, thus making flooding a complex phenomenon to study (Junk et al., 1989; Tockner and Stanford, 2002). Fluvial flooding tends to occur when excessive rain falls over an extended period of time, leading to a river exceeding its capacity, or because of heavy snow that subsequently melts and, via surface runoff, rapidly fills the river channels when infiltration is low because of frozen soils below the snow layer (Blöschl et al., 2017).

River flow regimes are affected by the increased rainfall and this also has the potential to affect erosion and generate additional sediment loads and particulate organic matter (POM) for deposition within river channels, lakes and estuaries (Arnell et al., 2015; Le Gall et al., 2018; Rinklebe and Du Laing, 2011). Intense rainfall over a short timescale (usually less than six hours i.e. "flash floods") can also cause rivers to overbank leading to an intense, high velocity torrent of water that moves through river beds, disturbing river sediments and potentially bringing more PTEs contamination with the flood water, greatly influencing the contaminated status of the floodplain (Blöschl et al., 2017; Maggioni and Massari, 2018). The water inundating the floodplain contains dissolved matter (i.e. free 
large organic and inorganic polymers, oxides, clay minerals and organic matter) (Kirk, 2004). The sediment loads travel at different rates due to their particle size, which reflects the texture of the river bed and bank (Malmon et al., 2004). Approximately $90 \%$ of PTEs load has been associated with sediment particles, with dissolved PTEs playing a comparatively minor role in pollutant transfer to floodplains (Ciszewski and Grygar, 2016). There have been many fluvial geomorphology studies showing how erosion and sedimentation have been influenced by climatic variability in the past (e.g. Lewin and Macklin, 2010; Macklin and Rumsby, 2007; Mullan et al., 2019), indicating that rivers are sensitive to climatic change (Arnell et al., 2015). Fluvial flooding is receiving increased scientific and political interest because of the potential impact that climate change may have on this type of flooding, with climate model projections showing an increased flood risk at a global scale (Pappenberger et al., 2012; Wilby et al., 2008).

In floodplains that are underlain by permeable deposits, increased rainfall causes groundwater to rise (leading to groundwater flooding), which can result from direct rainfall recharge, when the soil water storage potential is exceeded, as well as flow into the floodplain sediments from rivers with high water levels, and from areas inundated with fluvial flooding. However, good hydraulic connection between river and aquifer means that the aquifer can drain quickly as fluvial flood waters recess. Groundwater flooding in these settings is relatively short-lived compared with other groundwater flood settings, for example in chalk catchments (MacDonald et al., 2012).

With increased frequency of rainfall events predicted, it has become widely recognised that the storage of floodwater on floodplains can help to reduce the magnitude of a flood downstream. Thus, floodplains are useful for flood risk management (Acreman et al., 2003; Vink and Meeussen, 2007). As a result, floodplains may be deliberately managed to allow flooding to occur through engineered soakaways in order to protect an urban residential area (Lane, 2017; Wheater and Evans, 2009). It is important to understand the potential implications of these types of management practices 
on mobilisation of PTEs that may be associated with the sediments deposited on the floodplain during past flooding events.

\subsection{Changes that floodplain soils undergo during and after inundation}

Extreme rainfall events leading to flooding have generally been found to alter soil physical and chemical properties and influence biological processes (Harvey et al., 2019). The fluctuations between inundation and subsequent drying, associated with periodically flooded soils, are major drivers of spatial and temporal differences in soil properties that affect the biogeochemical processes taking place in floodplain soils (Schulz-Zunkel et al., 2015; Tockner et al., 2010). These changes include; a decrease in redox potential $\left(E_{H}\right)$, which leads to, for example, reduction of iron ( $F e$ ) and manganese (Mn), which in turn can influence the soil pH (Rinklebe and Shaheen, 2017). Other processes affected include sulphur-cycling, changes to the presence of chelating agents such as dissolved organic carbon, mineralisation of POM and suppression of microbial activity (Poot et al., 2007; Puchalski, 2003; SchulzZunkel et al., 2015; Schulz-Zunkel and Krueger, 2009). Ibragimow, Walna, and Siepak (2013) showed, through analyses of fluvial samples before and after a flood, that the physicochemical properties (grain size, $\mathrm{E}_{\mathrm{H}}, \mathrm{pH}, \mathrm{POM}$, and calcium carbonate contents) as well as the total and available concentration of PTEs had changed. Harvey et al. (2019) found that after UK floods receded in the winter of 2013-14 there was a decrease in the soil bulk density, $\mathrm{pH}$ and available $\mathrm{P}$. The flood was found to have had a negative effect on the overlying vegetation and caused a shift in the microbial community structure.

Inundation during a flooding event can carry PTEs dissolved in rising groundwater and potentially contaminated suspended sediment from upstream overbanking water, depositing this onto the floodplain during a flood (Acreman et al., 2003; Bednářová et al., 2015; Du Laing et al., 2009; Gröngröft et al., 2005; Junk et al., 1989; Rudiš et al., 2009; Tockner and Stanford, 2002; Weber et al., 2009). Subsequently, this deposition of suspended riverine sediments/POM by flood water results in

252 the floodplain topsoil becoming a sink for PTEs (Du Laing et al., 2009; Frohne et al., 2011; 253 Nshimiyimana et al., 2014; Overesch et al., 2007; Rinklebe et al., 2007; Visser et al., 2012; Zhao and 

concentrations of PTEs such as the metalloid; arsenic (As), and metals; chromium ( $\mathrm{Cr}$ ), copper (Cu), lead $(\mathrm{Pb})$, and zinc $(\mathrm{Zn})$, but later due to post-depositional reactions with organic matter/other organic components the PTEs concentrations will vary (Adekanmbi et al., 2020; Ciszewski and Grygar, 2016; Hurley et al., 2017; Izquierdo et al., 2013; Jiao et al., 2014; Kelly et al., 2020). When laboratory experiments are undertaken on samples gathered from floodplain site, soils are collected as single or composite samples, air or oven dried and then homogenised, resulting in a loss of soil stratigraphy and therefore the potential differences in PTEs concentration with depth may be unaccounted for (Ciszewski and Grygar, 2016). Zhao and Marriott, (2013) looked at PTEs concentrations along a vertical profile and found that there were peak values at varying depths; affected by translocation and duration of inundation. The process of breaking up of soil samples for laboratory experiments will make interpretation of PTEs levels difficult. Kelly et al. (2020) took intact soil cores to overcome this and more closely reflect natural samples, they too found the duration of inundation influenced the fate of PTEs.

The biological health of floodplain soils is important as they act as an interface between terrestrial and aquatic environments, therefore playing an important role in maintaining the environmental quality of surface waters (Izquierdo et al., 2013; Stuart and Lapworth, 2011). Artificial or constructed wetlands have been used for flood and pollution control; storing and filtering excess water to protect rivers from various kinds of runoff e.g. high nutrient loads from farm land (Blackwell and Pilgrim, 2011; Ellis et al., 2003; Rizzo et al., 2018). An example of this technology is demonstrated at the Rothamsted Research North Wyke experimental farm (Pulley and Collins, 2019). Even if river and groundwater water quality improves due to the implementation of more stringent environmental policy, contaminated floodplains remain as a legacy of historic upstream pollution (Bradley and Cox, 1990; Förstner, 2004; Kowalik et al., 2004). With increased frequency and duration of flooding, there is the possibility that changes to soil properties and biogeochemical processes will ultimately lead to the mobilisation of PTEs from floodplain soils (Ciszewski and Grygar, 2016; González-Alcaraz and van 

pollution to the surrounding environment (Kelly et al., 2020; Pulchalski, 2003; Schulz-Zunkel and Krueger, 2009), as shown in Figure 1. 


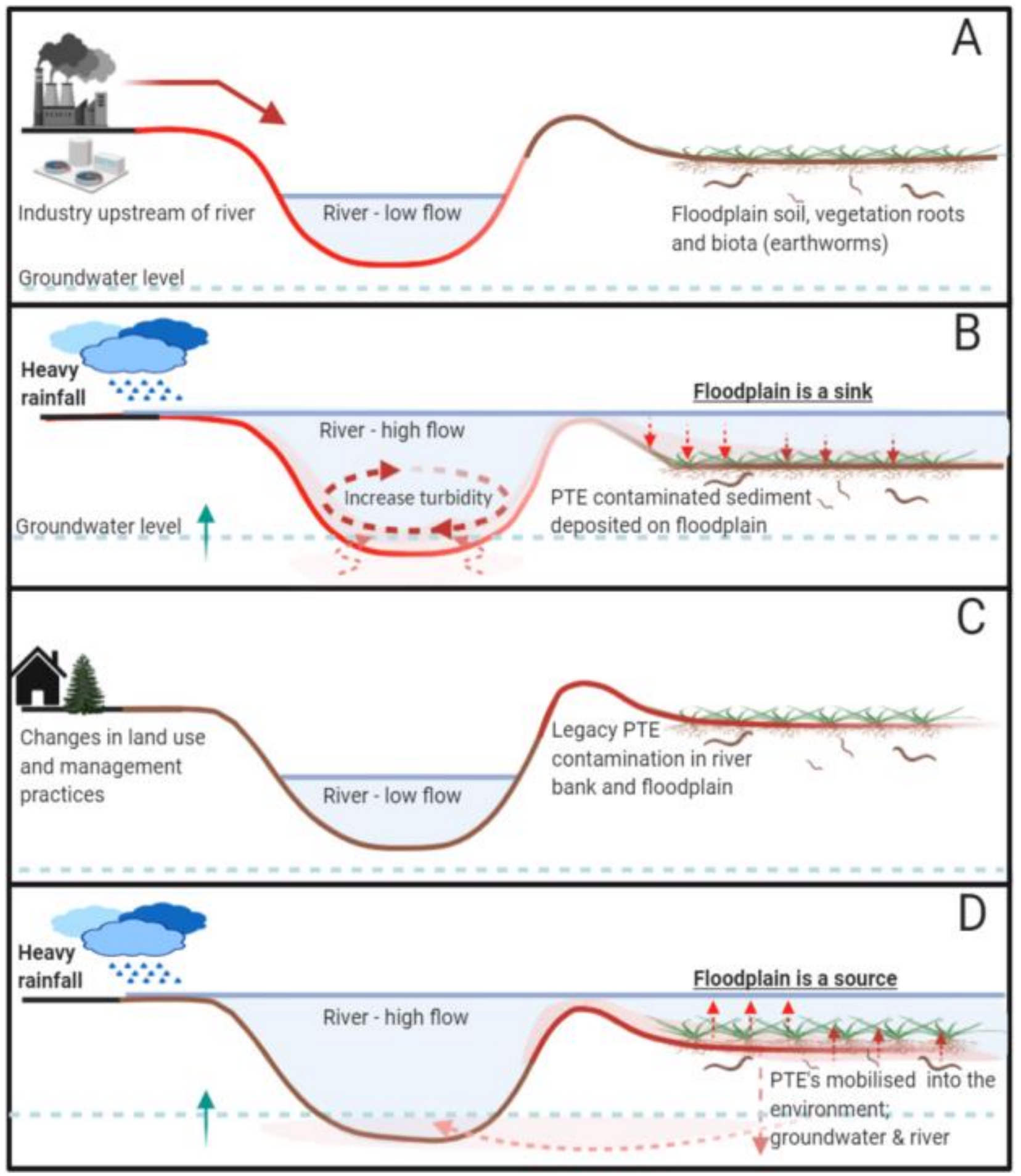

Figure 1: How floodplains may switch from being a sink of pollution to becoming a source of legacy pollution: A) PTEs contaminated river sediment (red) due to industry in the catchment upstream, B) heavy rainfall influences the receiving catchment (increased river flow and groundwater level), resulting in flooding and the deposition of contaminated sediment onto the adjacent floodplain; dissolved contaminants may also reach the floodplain surface via rising groundwater, C) Later, the river is uncontaminated (brown) due to rising environmental quality standards, with legacy of PTES contamination (red) in the river bank and floodplain soil, D) heavy rainfall results in flooding of the contaminated floodplain, mobilisation of the legacy PTEs by desorption and resuspended particulate matter into the surrounding environment and thus making them potentially available for uptake by 
vegetation and soil organisms, as well as pollutant transfer leaching into the overlying flood water, the groundwater, and ultimately the river. Created with BioRender.com.

\section{Impact of flooding on the mobility of potentially toxic elements in floodplain soil}

\subsection{PTEs in floodplain soil}

Several PTEs are also essential nutrients that are required in low concentrations for healthy functioning and reproduction of microorganisms, plants, and animals, although may become toxic in high concentrations, these include; $\mathrm{Cu}$, Cobalt (Co), Nickel (Ni), Vanadium (V), Zn, chlorine (Cl), Mn, Fe, boron (B), and molybdenum (Mo) (Adamo et al., 2014; Hooda, 2010; Wyszkowska et al., 2013). Other PTEs are non-essential and can cause toxicity even when they are found at low concentrations, these include; $\mathrm{As}, \mathrm{Pb}$,) and mercury (Hg); (Adamo et al., 2014; Nriagu et al., 2007; Wuana et al., 2011; Wyszkowska et al., 2013). Cadmium (Cd) is generally considered a non-essential element to soil organisms, but it has been found to be beneficial to some microalgae (Xu et al., 2008) Chromium can be considered a micronutrient but its toxicity depends on its valence state (i.e. $\mathrm{Cr}(\mathrm{VI})$ is the more mobile and toxic form compared with $\mathrm{Cr}(\mathrm{III}))$. Redox potential therefore not only affects the mobility of PTEs, but also their toxicity (Lee et al., 2005; Shahid et al., 2017). The consequences of PTEs contamination of soils are rarely observed with immediate effect, rather they tend to cause delayed adverse ecological changes, due to the fact that PTEs are persistent in the environment for long periods, non-biodegradable and can only be bio-transformed through complex physico-chemical and biological processes (Chrzan, 2016; Czech et al., 2014; Hooda, 2010). PTEs cause adverse ecological effects on plants and organisms such as impacting their activity, growth rate/yield, metabolism and reproduction, causing symptoms of physiological stress and potentially death. The extent of the adverse effect depends on the exposure route (ingestion, dermal absorption or uptake of pore water) and time, resistance (related to residence time of the PTEs in the environment) and detoxification mechanisms of the plant or animal (Alloway, 2013; Eggleton and Thomas, 2004; Ehlers and Loibner, 2006; Hooda, 2010; Pan et al., 2018; Shahid et al., 2017; Winger et al., 1998). Leaching of PTEs from 
the floodplain soil into the groundwater or river will also cause adverse effects to aquatic organism in these environments (Zia et al., 2018).

PTEs are either present naturally in the floodplain soil from the underlying or upstream geology and subsequent geogenic processes (e.g. weathering of parent material, emissions from volcanoes, forest fires) or introduced by anthropogenic sources, including solid and dissolved inputs from; aerial deposition, transport emissions, industrial, municipal and diffuse runoff from agricultural practices landfills and sewage treatment facilities (Alloway, 1995; Álvarez-Ayuso et al., 2012). PTEs can be adsorbed to colloidal suspended particulate material, transported in the river water and accumulate in the floodplain soil during inundation (Du Laing et al., 2009; Frohne et al., 2011; Peijnenburg et al., 2007; Rinklebe et al., 2007). PTEs have been found to be primarily associated with fine-grained clay or silt minerals and can reside in the floodplain for longer when compared with river sediments, as they are less likely to be susceptible to erosion (Lučić et al., 2019; Malmon et al., 2002). Contamination of the floodplain soil may result from a point source such as a sewage treatment facility, or from diffuse sources that have no specific point of discharge (e.g., agricultural applications). Impacts of diffuse pollution are difficult to predict as they can be affected by weather systems, meaning soils far from the source may be affected (Gregory et al., 2015; Neal et al., 1996). The anticipated changes to intense rainfall may result in increased delivery of diffuse pollution to rivers and groundwater (Arnell et al., 2015; Foulds et al., 2014), particularly as contaminated floodplain soils may become a diffuse source of pollution themselves during a flooding event (Schulz-Zunkel and Krueger, 2009).

\section{2. Influence of flooding on PTEs mobility}

During a flooding event, biogeochemical processes occur in the floodplain soil at the oxicanoxic interface and in the anoxic layers. The kinetics of these processes are of great importance because the location of the oxic-anoxic interface is subject to change due to fluctuating water table levels (Du Laing et al., 2009; Puchalski, 2003). In their review of trace metal behaviour in floodplain 
sediments, Du Laing et al. (2009) state that the spatial occurrence of processes affecting metal mobility and availability is largely determined by the topography of the floodplain. Remobilisation of PTEs from sediments into the overlying water column during a flooding event depends on the flood regime; the frequency of these intense floods which flush or remobilise contaminated material as well as the duration or alternation of flood with dry spells (Arnell et al., 2015; Foulds et al., 2014; González-Alcaraz and van Gestel, 2015). Whilst research has suggested that the longer the flood duration, the greater the metal mobility (Shaheen et al., 2014a, 2014b), Stafford et al. (2018) suggest that even short periods of soil saturation can have an influence the solubility of PTEs.

There are conflicting results in the literature regarding the effect of flooding on the mobility of PTEs, expressed by changes in PTEs concentration (increase or decrease), in floodplain soils (Table S1). This may largely be the result of different site-specific conditions (e.g. soil pH, texture, mineralogy) or different laboratory set-ups (e.g. submerging soils in deionised water, or the use of inert gas to simulate the anoxic conditions of a flood), illustrating the complexity of the processes involved in mediating PTEs mobility in floodplain soils (Abgottspon et al., 2015; Du Laing et al., 2007; Frohne et al., 2011; Schulz-Zunkel et al., 2015). Many of the considerations in the literature are founded on research of soils or sediments in microcosm experiments, which often involves homogenising the soil samples, resulting in loss of natural soil structure, loss of roots and biota, short-exposure time to flood conditions, and the control of variable factors such as temperature and soil water conditions (Frohne et al., 2011; Rinklebe et al., 2010). Redox conditions are often simulated and controlled through additions of $\mathrm{O}_{2}$, to increase $\mathrm{E}_{\mathrm{H}}$, and $\mathrm{N}_{2}$, to lower $\mathrm{E}_{\mathrm{H}}$ (Frohne et al., 2014, 2011; Schulz-Zunkel et al., 2015; Shaheen et al., 2016; Shaheen and Rinklebe, 2017). These differences make extrapolation of these laboratory-based findings to field situations difficult (Hooda, 2010).

A key factor in determining the fate and transport of PTEs is their chemical form which, in combination with environmental factors, can influence their mobility in the soil. The chemical form of 
Wuana et al., 2011). There are important redox sensitive PTEs for which the oxidation state has a large influence on solubility and mobility. For example, $\mathrm{Cr}(\mathrm{VI})$ is more mobile than $\mathrm{Cr}(\mathrm{III})$, but $\mathrm{As}(\mathrm{V})$ is less mobile than As(III) (Frohne et al., 2015; Rinklebe et al., 2016; Schulz-Zunkel et al., 2015; Shaheen et al., 2014b; Yang et al., 2015). Speciation of PTEs within the environment has a distinct influence upon their behaviour; specifically, reactivity, toxicity, mobility and bioavailability within the floodplain (Du Laing et al., 2009; Gambrell, 1994; Hooda, 2010; Rodgers et al., 2015). This understanding is important for predicting the environmental impact of contaminated soils, although we are only beginning to converge on consensus on how bioavailability or speciation soil tests can help with risk-assessments, while this is slowly introduced into legislation (Cipullo et al., 2018; Naidu et al., 2015, 2008; Ng et al., 2015).

\section{3. Changes to soil physical and chemical properties that influences PTEs mobility}

Potentially toxic elements present in soils are often adsorbed to or protected within aggregates that are stabilised by organic matter. During a flooding event, these particles may be leached through the soil profile, or suspended in flood waters where they may be redistributed across floodplain soils, or be carried downstream by the river, potentially contributing to river pollution of the contamination of downstream floodplains. The solubility and therefore mobility of PTEs from the soils to the surrounding environment depends largely on the intrinsic soil physical and chemical properties (texture, availability of soil particulate surfaces and dissolved organic matter, salinity and the presence of $\mathrm{Fe} / \mathrm{Mn}$ oxides, carbonates, phosphates and sulphides) and a range of variables that are directly affected by periodic inundation of the floodplain, including; soil $\mathrm{pH}$, redox potential $\left(\mathrm{E}_{\mathrm{H}}\right)$, dissolved organic carbon (DOC) and the valance of individual PTEs (Adewuyi and Osobamiro, 2016; Dawson et al., 2010; Du Laing et al., 2009; Frohne et al., 2015; González-Alcaraz and van Gestel, 2015; Lee et al., 2005; Puchalski, 2003; Rinklebe and Du Laing, 2011; Schulz-Zunkel and Krueger, 2009; Shaheen et al., 2016; Shaheen and Rinklebe, 2014; Steinnes, 2013). A conceptual model (Figure 2) has been produced based on our literature review (Table S1) as a way of visualising the various factors and processes influencing the solubility of PTEs in a floodplain soil. 

soil solution or porewater, and transferred through the ecosystem and food web to other terrestrial or riparian areas downstream from the floodplain; thus potentially becoming a risk to human and

Figure 2: Conceptual model depicting the key processes influencing the solubility of Potentially Toxic Elements (PTEs) after a soil becomes flooded.

a) Oxygen is rapidly consumed by microbial and root respiration, decreasing the redox potential $\left(E_{H}\right)$. b) Decreasing $E_{H}$ can lead to redox sensitive elements (e.g. As and $\mathrm{Cr}$ ) changing valence state, directly affecting solubility. c) Greater soil moisture brings dissolved organic matter (DOM) into solution. d) Reducing conditions (lower $E_{H}$ ) leads to the release of more DOM. e) Lower $E_{H}$ results in the reduction of Fe and $\mathrm{Mn}$, consuming protons $\left(\mathrm{H}^{+}\right)$and increasing $\mathrm{pH}$. $f$ ) an increase in $\mathrm{pH}$ often results in the release of more DOM. g) DOM acts as a chelating agent, forming soluble organo-metal complexes with PTEs desorbed from soil surfaces. $h$ ) as $\mathrm{pH}$ increases metal cations (e.g. $\mathrm{Cu}, \mathrm{Pb}, \mathrm{Zn}$ ) are adsorbed on $\mathrm{pH}$ dependent adsorption sites of particulate matter. i) as $\mathrm{pH}$ increases, anions and oxy-anions (e.g. As) are desorbed from $\mathrm{pH}$-dependent adsorption sites. j) Dissolution of reducible $\mathrm{Fe}$ and $\mathrm{Mn}$ oxides is facilitated by increasing $\mathrm{pH}$. k) Microbial reduction of $\mathrm{Mn}$ and Fe oxides increases their solubility and can cause reductive dissolution of co-precipitated PTEs. I) An increase in $\mathrm{pH}$ facilitates the precipitation of insoluble metal sulphides. $m$ ) Microbial reduction of sulphate results in the precipitation of metal sulphides. n) Release of adsorbed PTEs from soil surfaces increases PTEs solubility. o) Immobilisation of PTEs through adsorption processes reduces PTEs solubility. p) Reductive dissolution of PTEs associated with Fe and Mn oxides increases PTE solubility. q) Precipitation of PTEs as metal sulphides decreases PTEs solubility.

PTEs (Hooda, 2010). These processes include; sorption, desorption, dissolution and precipitation (Puchalski, 2003; Wijngaard et al., 2017). Subsequently, PTEs are redistributed into different geochemical fractions, associated with other soluble species, released from the soil matrix into the environmental health (Adamo et al., 2014; Adewuyi and Osobamiro, 2016; Baran and Tarnawski, 2015; 
Dang et al., 2002; Du Laing et al., 2009; Rinklebe et al., 2016; Schulz-Zunkel et al., 2015; Shaheen et al., 2014a, 2014b; Sizmur et al., 2011). Sorption processes that control PTEs mobility and bioavailability in soil are affected by the soil $\mathrm{pH}$, redox and their interactions with other ions and substances present in soil solution (Antoniadis et al., 2018; Frohne et al., 2011; Ostergren et al., 2000; Violante, 2013). with regards to soil moisture content, temperature and redox potential. The mobility of PTEs in flooded soils is closely related to changes in redox potential which, in turn, is altered by flooding. This can have direct impacts on the mobility of redox sensitive PTEs (e.g. As and $\mathrm{Cr}$ ). Inundation of soils with floodwater may indirectly affect PTEs mobility and speciation because it also influences, the population, community composition, and behaviour of invertebrates inhabiting the floodplain which, in turn, influence the mobility of PTEs through their burrowing and bioturbation behaviour. For example, earthworms are known to increase the mobility of PTEs due to passage through the earthworm gut (Sizmur et al., 2011; Sizmur and Richardson, 2020) and their populations are supressed by flooding events (Plum and Filser, 2008; Kiss et al., in review). Bioturbation/bioirrigation behaviour by chironomid larvae has been found to increase oxygen uptake at the soil/sediment-water interface, promoting POM decomposition that results in the release of dissolved organic matter and subsequent release of PTEs (He et al., 2019). Furthermore, the reduction of $\mathrm{Mn}$ and Fe can cause reductive dissolution of co-precipitated PTEs, and an increase in $\mathrm{pH}$ facilitates the precipitation of PTEs as insoluble sulphides. The mobility of PTEs can therefore increase or decrease due to the net effect of these processes (Figure 2). Which process dominates will depend primarily on the mineralogy of the soil.

The following sub-sections will explain how key soil physical and chemical properties are affected by flooding and how this influences PTEs mobility, followed by a discussion on the role of soil organisms and plants in mediating PTEs mobility in floodplain soils. Attention will be given to how each of these factors influence each other to distinguish direct and indirect impacts on PTEs mobility. 


\subsubsection{Soil texture and related properties}

Soil texture is a stable property that refers to the physical composition of mineral fragments; sand, silt and clay and varies due to differences in underlying or upstream geology. The texture and related clay mineralogy reflect the particle/pore size distribution and overall soil surface area (Amacher et al., 1986) which, in turn, affects the soils' water holding capacity (WHC); the maximum quantity of water a soil can potentially contain, also known as the field capacity (Stürck et al., 2014). Therefore, soil physical properties play a role in flood duration because they determine the soils' ability to receive (via infiltration) and drain water during a rainfall event (Rinklebe et al., 2007). Clayey soils are likely to be saturated for longer than freely draining sandy soils (Sherene, 2010). Soil hydraulic (water retention and hydraulic conductivity curve) as well as thermal properties (thermal conductivity and heat capacity) affect the hydrothermal regime of the soil. Together these properties determine the ease in which water, and dissolved PTEs, moves through the soil pore continuum, how much water can be stored in the pore volume, and how soil temperature varies with depth. These properties are strongly dependent on soil texture, pore size distribution and mineralogy (Hillel, 1998; Tack et al., 2006; Thomas et al., 2016). Soil temperature affects the flow of water through the soil due to changes in viscosity and hence affects infiltration calculations (Gao and Shao, 2015; Prunty and Bell, 2005), so this is often corrected for when reporting hydraulic conductivity data (Thomas et al., 2016).

PTEs must be in the soluble phase or associated with colloids to be transported through the soil. The soil properties will play a part in the movement of PTEs into and out of the soil solution. Clay minerals and organic matter compounds have a large number of binding sites, so act as adsorption surfaces for PTEs in soils. The type of clay mineral present (kaolinite, illite, montmorrilonite etc.) will also affect the specific surface area (Meegoda and Martin, 2019; Tack et al., 2006). As a result, soils with high clay and silt (fine fractions) tend to retain higher amounts of PTEs, compared to course textured sandy soils (Sherene, 2010; Zhao et al., 1999). 


\subsubsection{Organic matter}

Soil POM, along with the surfaces of clay particles and Fe and Al oxides, acts as a binding phase for PTEs due to the attraction of positively charged cations to negatively charged surfaces (Evans, 1989). Thus, dissolved organic matter raises the cation exchange capacity (CEC) of a soil, and is thus considered to be an important factor controlling PTEs distribution and mobility in floodplain soils and sediments (Baran and Tarnawski, 2015; Bufflap and Allen, 1995; Du Laing et al., 2009; Ehlers and Loibner, 2006). The mechanisms that bind the PTEs with particulate and dissolved organic matter include adsorption, complexation and chelation (Alvim Ferraz and Lourenço, 2000; He et al., 2019; Selinus et al., 2005). Floodplains are subject to changing water table levels and occasional inundation that brings about associated changes in redox conditions. This can result microbially mediated soil POM degradation, either during prolonged periods of flooding or in the subsequent oxidising conditions when the flood recedes, which releases organically bound PTEs, such as $\mathrm{As}, \mathrm{Cu}, \mathrm{Co}, \mathrm{Cr}, \mathrm{Ni}$, $\mathrm{Pb}$, and $\mathrm{Zn}$ from the soil into the soil solution (Adewuyi and Osobamiro, 2016; Alvim Ferraz and Lourenço, 2000; Dang et al., 2002; Kalbitz and Wennrich, 1998; Koretsky et al., 2007; Rinklebe and Du Laing, 2011). Therefore, the extent to which flooding of soils results in the mobilisation of PTEs into solution is mediated by the proportion of the PTEs that are associated with soil POM, and the susceptibility of this organic matter to degradation (as a result of microbial activity (Fe(III) and Mn(IV)reducing micro-organisms) under reducing conditions. The free ions that are then in solution are highly reactive with the solid phase and are thought to be a major determinant of bioavailability and causing the most significant biological effects (Bufflap and Allen, 1995; Dang et al., 2002; Dawson et al., 2010; Degryse et al., 2009; Lloyd, 2003).

\subsubsection{Salinity}

Salinity is proportional to the conductivity of a sample solution; which is a measure of its ability to conduct or carry electric current and depends on the presence of charged ion species (anions and cations) (Ander et al., 2016; de Souza Machado et al., 2018; De Vivo et al., 2008)). Increasing salinity in flood water is associated with an increase in major cations that compete with PTEs for sorption 
sites. This competition promotes PTEs desorption from the floodplain soil in the absence of sulphides and hence increases total PTEs concentrations in the soil porewater (Rinklebe and Du Laing, 2011). The presence of Ca-salts releases more PTEs into the soil solution compared with $\mathrm{Na}$-salts that are less competitive for sorption (Du Laing et al., 2009; Hahne and Kroontje, 1973).

Changes in salinity may affect the soil physical properties and result in a destabilisation of the soil structure (Gregory et al., 2015). The salinity of the water causes a neutralisation of negatively charged clay particles, followed by flocculation (particles attaching together) which increases the deposition of sediments (along with the PTEs adsorbed to them) onto the floodplain. This process results in the floodplain becoming a sink for PTEs (Rinklebe and Du Laing, 2011). An extended flood duration, particularly when accompanied by low flow-rates (including stagnant water), results in sedimentation of fine grain sediment and organic matter that may have PTEs bound (Ciszewski and Grygar, 2016; Du Laing et al., 2009; Shaheen and Rinklebe, 2014).

\subsubsection{Redox potential $\left(E_{H}\right)$}

Waterlogging of soils generally results in a reduction in oxygen availability due to rapid consumption of oxygen by soil microbial activity and root respiration (Du Laing et al., 2007; Rinklebe and Du Laing, 2011) and because the dissolution of oxygen through water is many times slower than through air (Alloway, 1995; Du Laing et al., 2009; Frohne et al., 2015; Schulz-Zunkel et al., 2015). The soil microbial community (e.g. bacterial species such as Thiobacillus ferroxidans, Thiobacillus thiooxidans and Leptospirillum ferrooxidans) then uses alternative electron acceptors (such as nitrate, sulphate and $\mathrm{Fe} / \mathrm{Mn}$ oxides), in anaerobic respiration, which results in a decrease in redox potential $\left(E_{H}\right)$ (Maluckov, 2017) as the floodplain soils change from oxic $\left([02]>30 \mu \mathrm{mol} \mathrm{L}^{-1}\right)$ to anoxic $\left([02]<14 \mu \mathrm{mol} \mathrm{L}^{-1}\right)$ conditions (Bellanger et al., 2004). Associated alkalinity generation drives increases in soil pH, a change which can be observed after a few days (Du Laing et al., 2007; Johnston et al., 2014; Karimian et al., 2017). Soil temperature has been found to dictate the rate and type of redox reactions; with soils at low temperatures $\left(1-4{ }^{\circ} \mathrm{C}\right)$ requiring greater durations of saturation (20 days) 
before the onset of reducing conditions were seen, whereas soils at higher temperatures (above $9^{\circ} \mathrm{C}$ ) only required 2 days of saturation (Vaughan et al., 2009).

Redox potential has important effects on the speciation of $\mathrm{As}, \mathrm{Cu}$ and $\mathrm{Cr}$, as well as $\mathrm{N}, \mathrm{S}, \mathrm{Fe}$, $\mathrm{Mn}$, because these elements can exist in soils in more than one oxidation state (Selinus et al., 2005) and solubility depends on oxidation state. Copper solubility decreases after reduction from $\mathrm{Cu}$ (II) to $\mathrm{Cu}$ (I) under anaerobic conditions and the presence of electron donors (Fe (II)) and bacteria. However, other PTEs such as $\mathrm{Cd}$ and $\mathrm{Zn}$ change valence state as a consequence of redox dependent $\mathrm{pH}$ changes, complexation with organic matter or precipitation with Fe and Mn (hydr)oxides or sulphides (Du Laing et al., 2009; Frohne et al., 2011).) Shaheen et al. (2014a) demonstrated that sufficient time is needed for transformations between valence states to take place. For example, the oxidation of $\mathrm{Cr}$ from $\mathrm{Cr}$ (III) to the highly mobile $\mathrm{Cr}$ (IV) form was found to be a slow process. This means that with shorter flooding duration and quicker cycling between oxic and anoxic conditions, $\mathrm{Cr}$ mobility may be difficult to predict.

The presence of variable charge minerals, such as Fe and Mn oxides, phosphates, carbonates and sulphides provide a reaction surface for sorption processes, allowing PTEs to bind and become immobilised (Antoniadis et al., 2018; De Jonge et al., 2012; Sipos et al., 2014; Violante, 2013). Reducing conditions change the oxidation state of $\mathrm{Fe}$ and $\mathrm{Mn}$, increase their solubility and may have indirect effects (known as reductive dissolution) on the mobility of associated metal cations (e.g. As, Cd, Cu, $\mathrm{Ni}, \mathrm{Pb}$, and $\mathrm{Zn}$ ), releasing them from the solid phase to pore waters, depending on flood duration (Abgottspon et al., 2015; Ciszewski and Grygar, 2016; Du Laing et al., 2009; Frohne et al., 2011; Karimian et al., 2017; Rinklebe and Du Laing, 2011; Schulz-Zunkel et al., 2015; Shaheen et al., 2016, 2014b; Vaughan et al., 2009). Redox processes are a key factor for the reductive dissolution of $\mathrm{Mn}$ and Fe (hydr)oxides, these processes are often catalysed by microorganisms and result in the release of PTEs from the sediment (Du Laing et al., 2009; Frohne et al., 2011; Stafford et al., 2018; Yang et al., 2015). Relatively insoluble Fe(III) and Mn(IV) prevail under aerobic soil conditions providing sorption 
surfaces for many metals, whereas under anaerobic conditions $\mathrm{Mn}(\mathrm{IV})$ and $\mathrm{Fe}(\mathrm{III})$ are reduced to more soluble forms ( $\mathrm{Mn}(\mathrm{II})$ and $\mathrm{Fe}(\mathrm{II}))$ with consequential dissolution of $\mathrm{Mn}$ and Fe hydrous oxides, cosorbed PTEs ions (e.g. As, $\mathrm{Cd}, \mathrm{Cr}$, Ni and Pb), are released into soil solution (Simmler et al., 2017; Stafford et al., 2018; Yang et al., 2015). After inundation, Fe and Mn may re-precipitate as oxides and can bind (by desorption or co-precipitation) the trace metals back into the solid state (Ciszewski and Grygar, 2016; Davranche et al., 2011; Du Laing et al., 2009).

Decreasing of $\mathrm{E}_{\mathrm{H}}$ can initiate microbial sulphate reduction and this can reduce the mobility of some PTEs (e.g. As, $\mathrm{Cd}, \mathrm{Cu}, \mathrm{Cr}, \mathrm{Ni}$ and $\mathrm{Pb}$ ) through coprecipitation of metal cations with sulphides (Abgottspon et al., 2015; Borch et al., 2010; Weber et al., 2009), although many of these minerals are metastable and so prone to change (Karimian et al., 2018). Yang et al., (2015) put mixed sediment samples into a laboratory culture tanks and found that microbially induced release of sulphur with subsequent As precipitation was more important for controlling As adsorption/desorption than reductive dissolution of $\mathrm{Fe} / \mathrm{Mn}$ oxides. As the flood recedes, the floodplain soils undergo drying and aeration that change the conditions from anoxic back to oxic. The now oxic environment causes sulphides to be oxidised, which then releases PTEs back into the pore waters (Abgottspon et al., 2015; Du Laing et al., 2007; Frohne et al., 2011). In addition to this, when exposed to oxygen and water, sulphides are oxidised to sulphates which leads to the formation of sulphuric acid thereby causing a decrease in $\mathrm{pH}$ and release of the PTEs (Emerson et al., 2017; Forstner and Wattman, 1981). Frohne et al. (2011) suggested that the mobility of $\mathrm{Cd}, \mathrm{Cu}, \mathrm{Mn}, \mathrm{Ni}$ and $\mathrm{Zn}$ under oxidising conditions could be attributed to dissolution of sulphides and the resulting release of those metals. The extent to which the mineralogy of a floodplain soil is dominated by Fe/Mn oxides or sulphates may dictate whether PTEs are mobilised or immobilised during inundation, and the extent to which this phenomenon is reversed after floodwater recedes. 
$\mathrm{pH}$ is a measure of the hydrogen ion concentration and can also be referred to as the degree of acidity or alkalinity. The soil pH is affected by flooding because of a well-established correlation between soil pH and changing redox conditions; as a soil becomes flooded, this creates reducing conditions where ( $\mathrm{H}^{+}$ions) are consumed (for example due to reduction of $\mathrm{Fe}$ and $\mathrm{Mn}$ oxides) and the pH increases (Rinklebe and Shaheen, 2017; Weber et al., 2009). When the flood recedes, oxidation processes produce protons and decrease the $\mathrm{pH}$ (Adewuyi and Osobamiro, 2016; Frohne et al., 2015, 2011; Rinklebe and Shaheen, 2017; Shaheen and Rinklebe, 2017). Furthermore, on exposure to the atmosphere, when flooding recedes, dissolved organic carbon (DOC) is converted to $\mathrm{CO}_{2}$, which dissolves into porewater as carbonic acid, subsequently further reducing the soil pH (Peacock et al., 2015). However, this negative correlation between $\mathrm{E}_{\mathrm{H}}$ and $\mathrm{pH}$ hasn't always been observed (Du Laing et al., 2009; Frohne et al., 2015). This is because the degradation of POM such as plant residues, by soil microbes, may increase the soil pH due to ammonification of the residue $\mathrm{N}$ (Xu et al., 2006). of PTEs from organic matter or clay minerals occur, altering the chemical composition as well as reaction rates (Frohne et al., 2011). The soil pH plays an important role in mediating the mobility of PTEs and their availability for plant uptake, as the protons compete with metal cations for exchange sites on the surface of soils. Some of these exchange sites, particularly those associated with soil organic matter, are $\mathrm{pH}$-dependent and thus only become deprotonated at high $\mathrm{pH}$. A decrease in $\mathrm{pH}$ is generally accompanied by an increase in the mobility of most PTEs that are metal cations (e.g. $\mathrm{Cd}^{2+}$, $\mathrm{Cu}^{2+}, \mathrm{Co}^{2+}, \mathrm{Ni}^{2+}, \mathrm{Pb}^{2+}$ and $\mathrm{Zn}^{2+}$ ) (Gröngröft et al., 2005; Sherene, 2010). Thus, as $\mathrm{pH}$ increases there is a subsequent decrease in the mobility of these PTEs (Giacalone et al., 2005). The extent to which PTEs mobility decreases in soils during flooding, due to a redox-induced increase in $\mathrm{pH}$, is likely to depend on the proportion of PTEs in the soil that are associated with $\mathrm{pH}$-dependent exchange sites) which are typically associated with soil organic matter) and the $\mathrm{pH}$ of the soil prior to the flooding event. 


\subsubsection{Dissolved organic matter (DOM)}

The increase in $\mathrm{pH}$ of soil solutions with lower redox potential (reducing conditions) is often accompanied by a release of dissolved organic matter (DOM) and the subsequent formation of soluble organo-metal complexes (Abgottspon et al., 2015; Alvim Ferraz and Lourenço, 2000; Frohne et al., 2011). The presence of DOM in floodplain soils acts as a chelating agent which has a strong binding ability and increases the mobility of PTEs into pore waters and subsequently into river water or groundwater (Dawson et al., 2010; Du Laing et al., 2009; Shaheen et al., 2014b). The greater the concentration of DOM in porewater, the more PTEs that are held in solution, and (to maintain an equilibrium) the more PTEs that desorb from the surfaces of the soil to replenish the free ion concentrations in the porewater, thus increasing PTEs mobility. Greater concentrations of DOM have been observed with decreasing $\mathrm{E}_{\mathrm{H}}$, which may be due to supressed microbial carbon consumption under anoxic conditions (Frohne et al., 2015). Shaheen et al. (2014a) highlighted that increases in DOM associated with lower $E_{H}$ may help to catalyse changes in the valence state of PTEs; for example, of Chromium (III) to (VI).

\subsubsection{Temperature}

As temperatures are predicted to increase as a result of climate change, they may become a factor that contributes to greater release of PTEs from the soil during a flood (Visser et al., 2012). Soils are affected by variations in air temperature which, in turn, affects the rate of biogeochemical processes during a flooding event, including decreasing redox potential and, ultimately, influences the rate and extent to which PTEs are released/ desorbed from POM into surface water and groundwater (Arnell et al., 2015; González-Alcaraz and van Gestel, 2015; Sánchez-Rodríguez et al., 2019; Shaheen et al., 2016; Stahl et al., 2013). Increases in temperature raise the ion activity in soil solution, and also make plants more active, which may lead to greater plant root uptake of soil water and dissolved/labile PTEs within this water (Sherene, 2010). Arsenic release from flooded soils was found to have temperature dependence, with As solubilisation increasing as temperature increased (Simmler et al., 2017; Visser et al., 2012). Temperature increases are attributed to a decrease in the 
water viscosity resulting in dissociation of molecules and a subsequent increase in the number of ions in the solution. For every degree Celsius increase in temperature there is an observed increase in electrical conductivity of 1.9\% (Ander et al., 2016; Ma et al., 2011). mediated and temperature dependent, and so the extent to which they affect the mobility of PTEs depends on their kinetics and the duration that floodplain soils are inundated. Changes in soil pH and DOM have been shown to exert a greater influence than $\mathrm{E}_{\mathrm{H}}$ on the mobility of PTEs when considering shorter flood-dry cycles (Shaheen et al., 2014b, 2014a). However, Dang, Liu, and Haigh (2002) found that with increasing flood duration, more trace elements were transformed from inert phase to exchangeable fractions, increasing mobilisation. Soil redox processes are important for protecting environmental health; however, the kinetics and mechanisms remain poorly characterised and understood (Abgottspon et al., 2015; Borch et al., 2010; Pulchalski, 2003). Many of the studies reviewed in this manuscript undertook experiments in the laboratory at temperatures that are higher than the soil temperatures typically found in-situ at the location where the soil samples were collected, and so the rates at which reactions occur and the subsequent mobilisation of PTEs may be overestimated in these experiments. It is not possible to verify the extent of the overestimation, so more in-situ experiments are needed to investigate and provide quantification of the differences between laboratory and in-situ experiments. (Andersen, 2018). In warmer seasons they will generally be cooler than soil temperatures, but the opposite occurs in cooler seasons. Also, changes in soil moisture content, as a result of flood events, will affect the soil thermal properties such as thermal conductivity and heat capacity (Lu et al., 2007), thereby also affecting the spatial and temporal variation in the soils' temperature regime. A laboratory microcosm experiment with mining-contaminated topsoil and subsoil samples saturated for up to 41 
651 solubilisation of As, particularly in the topsoil when saturated for 1-2 weeks (Simmler et al., 2017).

652 This means, for some PTEs, flooding during warmer seasons may result in greater mobilisation than

653 flooding during cooler seasons. More seasonal field observations are required to understand the

654 subtle interactions and feedbacks between soil moisture, floodwater temperature, and mobility of 655 PTEs.

\section{4. Soil biological processes that influence PTEs mobility}

657

658

659

660

661

662

663

664

665

666

667

\subsubsection{Soil organisms}

Floodplain soils contain a great diversity of organisms that are known to contribute to the physical structure of the soil/sediment through bioturbation which influences the biogeochemical cycling of PTEs through oxygen diffusion, redox gradient and decomposition of dissolved organic matter (Classen et al., 2015; He et al., 2019; Hooda, 2010; Selinus et al., 2005). As the soil pore spaces are filled with water, oxygen diffusion is low so microbial respiration relies on alternative electron acceptors (e.g. $\mathrm{NO}_{3}^{-}, \mathrm{Mn}, \mathrm{Fe}$ and $\mathrm{S}$ ), resulting in reducing conditions (decreasing $\mathrm{E}_{\mathrm{H}}$ ) that simultaneously increase pH (Matern and Mansfeldt, 2016), and the changes to PTEs mobility (Figure 3) that are described in previous sections. Changes in the chemical speciation of PTEs can also occur due to microbial processes in reducing conditions, for example, sulphate reducing bacteria can methylate $\mathrm{Hg}$ in anoxic conditions (Ma et al., 2019). 


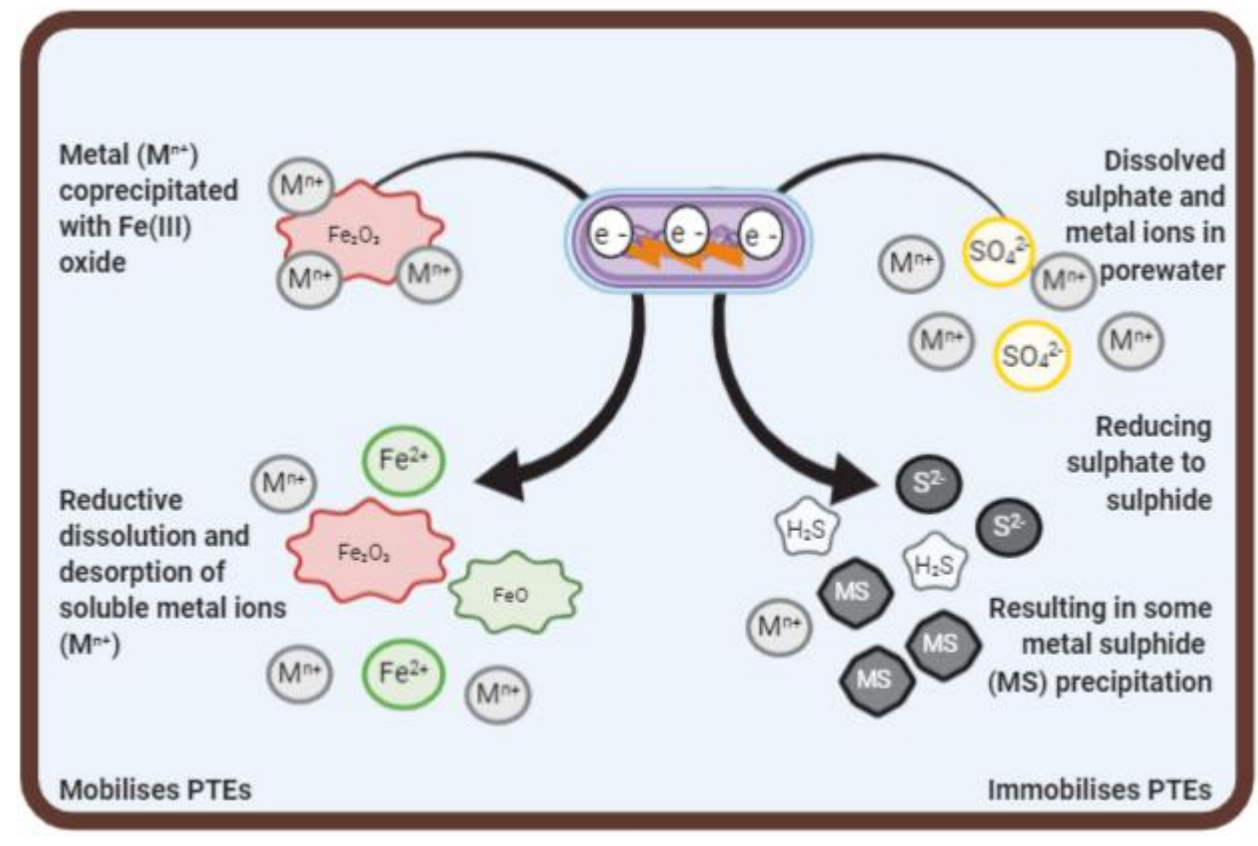

Figure 3: Soil microbial processes during inundation of floodplain soil influences mobility of PTEs; (lefthand side) generic metals with valence state (denoted by $\mathrm{M}^{\text {nt }}$ ) are coprecipitated to Fe oxides and are released due to reductive dissolution and (right-hand side) sulphate reduction (sulphate to sulphide) results in some metal (denoted by MS) precipitation, some of the metal $\left(\mathrm{M}^{n+}\right)$ remains in the pore water. Created with BioRender.com.

PTEs that are present in floodplain soils are often protected within the soils' aggregates, which are stabilised by POM. However, inundation can stimulate the soil microbial community, which is sensitive to disturbance, accelerating the refractory organic matter mineralisation and destabilisation of aggregates, exposing and increasing the mobility of PTEs in the soil (Du Laing et al., 2009; Gall et al., 2015; González-Macé et al., 2016; He et al., 2019; Rawlins et al., 2013). Tack et al. (2006) found that the drying of sandy soils caused an increase in soil solution metal concentrations, compared with the same soils maintained at field capacity. This observation was attributed to microbial effects, increasing the solubility of dissolved organic matter. changes include a reduction of Gram-positive bacteria, mycorrhizal fungi and earthworms found under flooded conditions (Gregory et al., 2015; Harvey et al., 2019; Unger et al., 2009). Harvey et al., (2019) found that flooding induced short-term alterations to soil microbial biomass but these changes did 
not persist in the long term; they concluded that temperate systems may be resilient to winter flood

688

689

690

691

692

693

694

695

696

697

698

699

700

701

702

703

704

705

706

707

708

709

710

711

712

stress. The seasonal timing of floods influences the effect that flooding has on the soil microbial community, and so may result in different effects on, and recovery of, the soil microbial community.

Sánchez-Rodríguez et al., (2019) subjected a UK agricultural grassland soil in an intact laboratory microcosm to flooding and found that summertime flooding $\left(25^{\circ} \mathrm{C}\right)$, resulted in a loss of actinomycetes and arbuscular mycorrhizal fungi, and that these changes persisted post-flood. They expected microbial biomass to increase with flooding at higher temperatures, due to degradation of vegetation releasing labile carbon. However, they found that maintaining live roots and an active rhizosphere were more important for preserving the microbial community in grassland soils. Earthworms also play a role in increasing the mobility and availability of PTEs in floodplain soil through their activity causing changes to the soil microbial populations, pH, DOC or metal speciation (Sizmur et al., 2011; Sizmur and Hodson, 2009) which in turn influences PTEs mobility as discussed in the above sections.

As the PTEs are released into the aqueous phase and mobilised in the environment, they present a potential risk to soil organisms (Ehlers and Loibner, 2006; González-Alcaraz and van Gestel, 2015). Soil organisms uptake PTEs via ingestion of polluted soil, food or pore water and/or via dermal uptake or absorption of soil water, with the soil water being the more important of the two pathways (Chrzan, 2016; Hobbelen et al., 2006; Sivakumar and Subbhuraam, 2005). Vijver et al. (2007) found that the frequency of flooding did not result in consistent changes in the internal PTEs concentrations of earthworms. Earthworms accumulate PTEs in their chloragogenous tissue and have a mechanism that allows them to regulate their internal PTEs concentrations, so when they are introduced to contaminated soils the earthworms reach an equilibrium and when they are returned to uncontaminated/"clean" soils they are able to detoxify and eliminate essential metals through excretion (e.g. $\mathrm{Cu}$ and $\mathrm{Zn}$ ), but not non-essential metals (e.g. $\mathrm{Cd}$ and $\mathrm{Pb}$ ) as detoxification processes involve sequestration within an inorganic matrix or organic ligand (Sizmur and Hodson, 2009; Spurgeon and Hopkin, 1999). While microbes can tolerate larger quantities of essential PTEs, in excess both essential and non-essential PTEs (e.g., Al, As, Cd, Hg, Pb, Zn) can adversely affect microbial 
communities by altering community structure and taxonomic richness; reducing the microbial biomass and lowering their enzyme activity which results in a decrease of soil diversity (Gadd, 2010; Gall et al., 2015; Wuana et al., 2011).

716

\subsubsection{Plants}

In many cases, PTEs are concentrated in the upper part of the soil profile where roots reside, meaning that increased mobility is likely to affect plants growing in floodplain soils. Wetland plants growing on inundated floodplain soils can also affect the mobility of PTEs because they are specially adapted to have air-filled tissues, or aerenchyma, which create patches of oxygenated soil around their roots, resulting in an increase in the volume of the oxic/anoxic interface and remobilising PTEs thus increasing their availability (Du Laing et al., 2009; Wright et al., 2017). However, in arable and pasture fields that are generally drier, flooding can cause crops to become stressed, as they are not adapted to wet soils. As oxygen levels decrease there is a build-up of carbon dioxide, methane and nitrogen gases that leads to the roots suffocating and dying (Hippolyte et al., 2012).

It is well established that symbiotic fungi, associated with plant roots, regulate the supply of micronutrients and reduce the uptake of non-essential PTEs by plants (Classen et al., 2015; Gadd, 2010; Tack, 2010). Plants, such as Artemisia and Phalaris species, on the floodplain excrete exudates during inundation which stimulates the activity of microbial symbionts in the rhizosphere, allowing PTEs to be taken up into the vegetation (Gall et al., 2015; Sullivan and Gadd, 2019; Violante et al., 2010; Xu et al., 2020). PTEs are often accumulated in plant root tissues and can sometimes be translocated into the plant shoots. However this is regulated in plants by the Casparian strip and therefore limited (Hooda, 2010; Nouri et al., 2009; Shahid et al., 2017). The uptake and accumulation of PTEs is element and plant-specific (Niu et al., 2007; Rinklebe et al., 2016; Tack, 2010; Violante et al., 2010; Xu et al., 2020). The mobilisation and uptake of PTEs by plants may pose a potential environmental risk (Shaheen and Rinklebe, 2014). European floodplains are most commonly used as grassland for grazing cattle or hay production, whereas in other regions e.g. India, they are used for 
crops like rice, which raises concerns for possible pollutant transfer from the floodplain soil into the surrounding water bodies, then uptake and potential biomagnification of PTEs into the food chain (Martin et al., 2014; Overesch et al., 2007; Tóth et al., 2016a). However, the hyperaccumulation of PTEs by some plants (e.g. sunflower, mustard (Brassicaceae), alfalfa and Ricinus) has resulted in them being considered for phytoremediation of contaminated floodplain soils (Gall et al., 2015; Niu et al., 2007; Nouri et al., 2009; Shaheen et al., 2016; Violante et al., 2010).

Factors influencing plant uptake of PTEs include soil pH, electrical conductivity and the total concentrations of PTEs in the soil (Nouri et al., 2009). PTEs uptake also depends on the concentrations in the soil solution, governed by plant exudates and root-induced changes to $\mathrm{pH}$ and DOM (Gall et al., 2015). Quantifying the total content of PTEs transferred into the food chain via plants growing on contaminated soil is difficult (Gröngröft et al., 2005). The concentrations of PTEs found in floodplain plants are not always directly reflected in the PTEs content found in the soil, due to both physiological and biochemical differences between different plant species; for example differences in the age of the plant biomass (seasonal trends in growth and therefore uptake of nutrients). Moreover, the rooting depth influences metal mobilisation/immobilisation and element specific uptake into the roots which also affects the transfer into the shoots(Chrzan, 2016; Overesch et al., 2007). Thapa et al. (2016) also demonstrated a change in semi-arid Australian floodplain vegetation productivity in response to flooding and drying cycles; flooding brings nutrients which increases net primary productivity. These changes in vegetation productivity could also initiate structural changes in floodplain vegetation communities in natural and semi-natural ecosystems (Overesch et al., 2007).

\section{Summary and further research needs}

\subsection{Summary of current understanding}

Floodplain soils downstream of urban catchments contain elevated concentrations of PTEs as a legacy of human activity and these PTEs could potentially be remobilised by future flooding events. A number of processes occur within the soil, ultimately determining PTEs fate. These processes 
include: sorption, desorption, complexation, precipitation and dissolution, transport of water and heat, and biological activity. The processes are influenced by the changing conditions that flooding brings particularly with regards to soil moisture content, temperature and redox potential. The mobility of PTEs in flooded soils is closely related to changes in redox potential which, in turn, is altered by flooding. These changes can have direct impacts on the mobility of redox sensitive PTEs (e.g. As and $\mathrm{Cr}$ ). Furthermore, the reduction of $\mathrm{Mn}$ and Fe can cause reductive dissolution of co-precipitated PTEs, but the reduction of sulphate can result in the precipitation of PTEs as insoluble metal sulphides. Which of these processes dominates will depend on the mineralogy of the soil. PTEs precipitated as metal sulphides may oxidise after floodwaters recede and mobilise, accelerated by the $\mathrm{pH}$ reduction caused by production of sulfuric acid. There are important interactions between redox potential and other soil properties, such as soil pH, moisture content, POM, DOM, temperature, and salinity which also have a strong impact on PTEs mobility (Vaughan et al., 2009). Many of these reactions are microbially mediated, temperature dependent and the kinetics in real-world scenarios are poorly understood. However, it seems that changes associated with alterations to $\mathrm{pH}$ and dissolved organic carbon are relatively fast, while changes to $E_{H}$ are slower and only become apparent after extended periods of flooding. In many cases, PTEs deposited due to legacy pollution events are concentrated in the upper part of the soil profile, meaning that increased mobility is likely to affect plants growing in floodplain soils and potentially lead to contamination of the surrounding environment, including overlying surface waters. chemical composition, and sediment load. They can be difficult to predict, due to their different types (e.g. overbanking or groundwater flooding), and the high variation in their magnitude, duration, and frequency of recurrence. Therefore, chemical, physical and biological data from floodplain soils immediately before and immediately after a flooding event are often lacking. However these data 
would provide the necessary insights into the factors and processes involved in altering the mobility of PTEs during and after a real flooding event (Barber et al., 2017). The effect of flooding on PTEs mobility can be difficult to predict due to there being several factors (e.g. speciation, release through biological degradation and competitive action of other ions) or interactions between factors (e.g. changes in $\mathrm{E}_{\mathrm{H}}$ caused degradation of POM) influencing PTEs mobility (Tack and Verloo, 1995).

Contamination of soil with PTEs receives most attention in highly contaminated urban, industrial, mining and waste disposal sites (Adamo et al., 2014; Resongles et al., 2015; Simmler et al., 2017; Wuana et al., 2011) with relatively little attention given to more 'typical' floodplains downstream of catchments with a history of urban and industrial development. Much of the work conducted to date (see Table S1) has been undertaken in Europe, America, Canada, China, Indonesia, Australia and New Zealand. Just over half of the studies cited in Table S1 were undertaken in Germany and Belgium (52\%), with a particular research effort around the River Elbe and Wupper River in Germany (Du Laing et al., 2009; Förstner, 2004; Frohne et al., 2011; Overesch et al., 2007; Rennert et al., 2017; Rinklebe et al., 2013; Shaheen et al., 2017). However, research examining the relationship between PTEs mobility and flooding in other parts of the world that are expected to see an increase in the frequency and magnitude of flooding events, for example in Asia, Africa and India, is limited.

A number of factors were identified that contribute to whether the mobility of PTEs will increase or decrease during inundation of a floodplain, which may be interconnected or work in combination to affect PTEs mobility. As a result, different soils with differing mineralogy and thus different biogeochemical and physical properties, will likely respond differently to flooding. Individual studies tend to focus on one floodplain site. However, knowledge based on one river catchment may not be particularly useful for predicting the impacts of flooding at another site with different mineralogy and physical and chemical characteristics. A more fundamental mechanistic understanding is required to inform the development of predictive models. Therefore, more coordinated work encompassing multiple contrasting sites is required to understand the relative importance of key soil 
properties (e.g. mineralogy, POM, soil pH, texture; and how these affect derived soil properties such as hydraulic and thermal soil properties) on influencing the impact of flooding on the mobility of PTEs. removal of plant roots, short-exposure time for soil microorganisms and incubation under controlled conditions, such as temperature (often higher than in-situ temperatures) and soil water conditions

821 (often wetting the samples with deionised water which is slightly acidic) (Frohne et al., 2011; Izquierdo 822 et al., 2017; Rinklebe et al., 2010; Weber et al., 2009). This makes extrapolation of laboratory-based 823 findings to field situations difficult (Hooda, 2010). Attempts to model the concentration of PTEs in floodplain pore waters have demonstrated the complexity of predicting how different variables such as soil moisture content and temperature interact and alter mobility (Rennert et al., 2017), with site or catchment-specific information being of great importance to establish and capture spatial differences sufficiently (Schulz-Zunkel et al., 2015). While much research undertaken in controlled conditions in laboratory microcosms is undoubtedly useful because independent replicates can be assigned to treatments without confounding variables (Figure 4), there is a clear research need for onsite experiments on the effect of flooding on PTEs mobility using real-time field-based observations that capture the kinetics of processes before, during, and after a flooding event under ambient temperatures and in geochemically contrasting soils. 

light levels:

i) Allows potentially

confounding variables to be regulated gradients are altered ii) Natural soil temperature

Controlled addition of water:

i) Flood depth, and duration/frequency

can be controlled

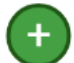

Artificial floodwater:

i) Floodwater chemistry can be controlled

ii) Artificial floodwater likely to differ from natural conditions

Absence of vegetation:

i) Above and below ground influence of vegetation removed

ii) Complexity and variability of plant physiology removed as potential confounding variable

Homogenised soil horizons:

i) Homogenised soil structure

(e.g. no macropores)

ii) Homogenisation allows

creation of identical replicates

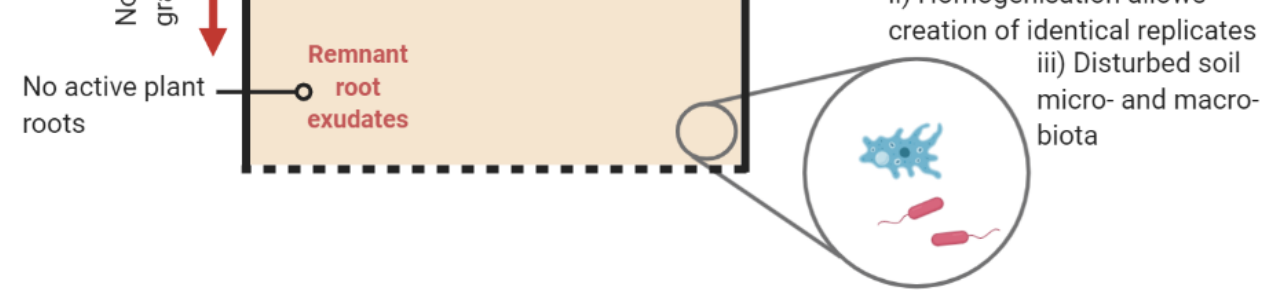

833

Figure 4: Strengths (+) and weaknesses (-) of laboratory-based studies for researching the impact of

835 flooding on mobility of PTEs. Created with BioRender.com.

836

837

\section{Acknowledgements}

Jessica Ponting is supported by a NERC SCENARIO PhD studentship, with CASE support from the British

Geological Survey Universities Funding Initiative.

840

841

\section{Supplementary Material}

842

One supplementary table (Table S1) is provided

References

845 Abgottspon, F., Bigalke, M., Wilcke, W., 2015. Fast colloidal and dissolved release of trace elements in a carbonatic soil after experimental flooding. Geoderma 259-260, 156-163. 
Acreman, M.C., Riddington, R., Booker, D.J., 2003. Hydrological impacts of floodplain restoration: a case study of the River Cherwell, UK, European Geosciences Union.

Adamo, P., lavazzo, P., Albanese, S., Agrelli, D., De Vivo, B., Lima, A., 2014. Bioavailability and soil-toplant transfer factors as indicators of potentially toxic element contamination in agricultural soils. Sci. Total Environ. 500-501, 11-22. https://doi.org/10.1016/J.SCITOTENV.2014.08.085

Adekanmbi, A.A., Shaw, L.J., Sizmur, T., 2020. Effect of Sieving on Ex Situ Soil Respiration of Soils from Three Land Use Types. J. Soil Sci. Plant Nutr. 1-5. https://doi.org/10.1007/s42729-02000177-2

Adewuyi, G.O., Osobamiro, M.T., 2016. Chemical speciation and potential mobility of some toxic metals in tropical agricultural soil. Res. J. Environ. Toxicol. 10, 159-165. https://doi.org/10.3923/rjet.2016.159.165

Alfieri, L., Bisselink, B., Dottori, F., Naumann, G., de Roo, A., Salamon, P., Wyser, K., Feyen, L., 2017. Global projections of river flood risk in a warmer world. Earth's Futur. 5, 171-182. https://doi.org/10.1002/2016EF000485

Alloway, B.J., 2013. Heavy Metals in Soils, Heavy Metals in Soils. https://doi.org/10.1007/978-94007-4470-7_10

Alloway, B.J., 1995. Heavy Metals in Soils: Trace Metals and Metalloids in Soils and their Bioavailability, 3rd ed. Springer, Heidelberg. https://doi.org/10.1007/978-94-011-1344-1

Álvarez-Ayuso, E., Otones, V., Murciego, A., García-Sánchez, A., Regina, I.S., 2012. Antimony, arsenic and lead distribution in soils and plants of an agricultural area impacted by former mining activities. Sci. Total Environ. 439, 35-43. https://doi.org/10.1016/J.SCITOTENV.2012.09.023

Alvim Ferraz, M.C.M., Lourenço, J.C.N., 2000. Influence of organic matter content of contaminated soils on the leaching rate of heavy metals. Environ. Prog. 19, 53-58. https://doi.org/10.1002/ep.670190118

Amacher, M.C., Kotuby-Amacher, J., Selim, H.M., Iskandar, I.K., 1986. Retention and release of metals by soils - Evaluation of several models. Geoderma 38, 131-154. https://doi.org/10.1016/0016-7061(86)90011-X

Ander, E.L., Watts, M.J., Smedley, P.L., Hamilton, E.M., Close, R., Crabbe, H., Fletcher, T., Rimell, A., Studden, M., Leonardi, G., 2016. Variability in the chemistry of private drinking water supplies 

and the impact of domestic treatment systems on water quality. Environ. Geochem. Health 38, 1313-1332. https://doi.org/10.1007/s10653-016-9798-0

Andersen, D.C., 2018. Flood effects on soil thermal regimes in contrasting cold-desert river floodplains (Yampa and Green rivers, Colorado). Ecohydrology 11, e1939. https://doi.org/10.1002/eco.1939

Antoniadis, V., Shaheen, S.M., Tsadilas, C.D., Selim, M.H., 2018. Zinc sorption by different soils as affected by selective removal of carbonates and hydrous oxides. Appl. Geochemistry 88, 49-58. https://doi.org/10.1016/J.APGEOCHEM.2017.04.007

Arnell, N.W., Halliday, S.J., Battarbee, R.W., Skeffington, R.A., Wade, A.J., 2015. The implications of climate change for the water environment in England. Prog. Phys. Geogr. Earth Environ. 39, 93120. https://doi.org/10.1177/0309133314560369

Baran, A., Tarnawski, M., 2015. Assessment of heavy metals mobility and toxicity in contaminated sediments by sequential extraction and a battery of bioassays. Ecotoxicology 24, 1279-1293. https://doi.org/10.1007/s10646-015-1499-4

Barber, L.B., Paschke, S.S., Battaglin, W.A., Douville, C., Fitzgerald, K.C., Keefe, S.H., Roth, D.A., Vajda, A.M., 2017. Effects of an Extreme Flood on Trace Elements in River Water - From Urban Stream to Major River Basin. Environ. Sci. Technol. 51, 10344-10356. https://doi.org/10.1021/acs.est.7b01767

Bednářová, Z., Komprdová, K., Kalábová, T., Sáňka, M., 2015. Impact of floods and their frequency on content and distribution of risk elements in alluvial soils. Water. Air. Soil Pollut. 226. https://doi.org/10.1007/s11270-014-2253-x

Bell, V.A., Kay, A.L., Cole, S.J., Jones, R.G., Moore, R.J., Reynard, N.S., 2012. How might climate change affect river flows across the Thames Basin? An area-wide analysis using the UKCP09 Regional Climate Model ensemble. J. Hydrol. 442-443, 89-104. https://doi.org/10.1016/J.JHYDROL.2012.04.001

Bellanger, B., Huon, S., Steinmann, P., Velasquez, F., Vall Es E, V., Arn, K., Clauer, N., Mariotti, A.E., 2004. Oxic-anoxic conditions in the water column of a tropical freshwater reservoir $\left(\mathrm{Pe}^{\sim}\right.$ naLarga dam, NW Venezuela), Published in Applied Geochemistry. https://doi.org/10.1016/j.apgeochem.2003.11.007 
Berz, G., Kron, W., Loster, T., Rauch, E., Schimetschek, J., Schmieder, J., Siebert, A., Smolka, A., Wirtz, A., 2001. World Map of Natural Hazards-A Global View of the Distribution and Intensity of Significant Exposures, Natural Hazards.

Blackwell, M.S.A., Pilgrim, E.S., 2011. Ecosystem services delivered by small-scale wetlands. Hydrol. Sci. J. 56, 1467-1484. https://doi.org/10.1080/02626667.2011.630317

Blöschl, G., Hall, J., Parajka, J., Perdigão, R.A.P., Merz, B., Arheimer, B., Aronica, G.T., Bilibashi, A., Bonacci, O., Borga, M., Čanjevac, I., Castellarin, A., Chirico, G.B., Claps, P., Fiala, K., Frolova, N., Gorbachova, L., Gül, A., Hannaford, J., Harrigan, S., Kireeva, M., Kiss, A., Kjeldsen, T.R., Kohnová, S., Koskela, J.J., Ledvinka, O., Macdonald, N., Mavrova-Guirguinova, M., Mediero, L., Merz, R., Molnar, P., Montanari, A., Murphy, C., Osuch, M., Ovcharuk, V., Radevski, I., Rogger, M., Salinas, J.L., Sauquet, E., Šraj, M., Szolgay, J., Viglione, A., Volpi, E., Wilson, D., Zaimi, K., Živković, N., 2017. Changing climate shifts timing of European floods. Science (80-. ). 357, 588590. https://doi.org/10.1126/science.aan2506

Borch, T., Kretzschmar, R., Skappler, A., Van Cappellen, P., Ginder-Vogel, M., Voegelin, A., Campbell, K., 2010. Biogeochemical redox processes and their impact on contaminant dynamics. Environ. Sci. Technol. https://doi.org/10.1021/es9026248

Bradley, S.B., Cox, J.J., 1990. The significance of the floodplain to the cycling of metals in the river Derwent Catchment, U.K. Sci. Total Environ. 97-98, 441-454. https://doi.org/10.1016/00489697(90)90255-S

Brönnimann, S., 2007. Impact of El Niño-Southern Oscillation on European climate. Rev. Geophys. 45, n/a-n/a. https://doi.org/10.1029/2006RG000199

Bronstert, A., 2003. Floods and Climate Change: Interactions and Impacts, Risk Analysis.

Bufflap, S.E., Allen, H.E., 1995. Sediment pore water collection methods for trace metal analysis: A review. Water Res. 29, 165-177. https://doi.org/10.1016/0043-1354(94)E0105-F

Chan, S.C., Kendon, E.J., Fowler, H.J., Blenkinsop, S., Roberts, N.M., 2014. Projected increase in summer and winter UK sub-daily precipitation extremes from high-resolution regional climate models [WWW Document]. Environ. Res. Lett. URL https://www.researchgate.net/publication/265090772_Projected_increase_in_summer_and_ winter_UK_sub-daily_precipitation_extremes_from_high-resolution_regional_climate_models (accessed 3.2.20). 
Chang, H., Franczyk, J., 2008. Climate Change, Land-Use Change, and Floods: Toward an Integrated Assessment. Geogr. Compass 2, 1549-1579. https://doi.org/10.1111/j.1749-8198.2008.00136.x

Chrzan, A., 2016. Monitoring bioconcentration of potentially toxic trace elements in soils trophic chains. Environ. Earth Sci. 75, 1-8. https://doi.org/10.1007/s12665-016-5595-4

Cipullo, S., Prpich, G., Campo, P., Coulon, F., 2018. Assessing bioavailability of complex chemical mixtures in contaminated soils: Progress made and research needs. Sci. Total Environ. 615, 708-723. https://doi.org/10.1016/j.scitotenv.2017.09.321

Ciszewski, D., Grygar, T.M., 2016. A Review of Flood-Related Storage and Remobilization of Heavy Metal Pollutants in River Systems. Water. Air. Soil Pollut. 227, 1-19. https://doi.org/10.1007/s11270-016-2934-8

Classen, A.T., Sundqvist, M.K., Henning, J.A., Newman, G.S., Moore, J.A.M., Cregger, M.A., Moorhead, L.C., Patterson, C.M., 2015. Direct and indirect effects of climate change on soil microbial and soil microbial-plant interactions: What lies ahead? Ecosphere 6, art130. https://doi.org/10.1890/ES15-00217.1

Clemente, R., Dickinson, N.M., Lepp, N.W., 2008. Mobility of metals and metalloids in a multielement contaminated soil 20 years after cessation of the pollution source activity. Environ. Pollut. 155, 254-261. https://doi.org/10.1016/j.envpol.2007.11.024

Czech, T., Baran, A., Wieczorek, J., 2014. Zawartość Metali Ciężkich W Glebach I Roślinach Z Terenu Gminy Borzęcin (Województwo Małopolskie) Content of Heavy Metals in Soil and Plants From an Area Borzęcin Municipality (Malopolska Province) 89-98. https://doi.org/10.12912/2081139X.20

Dadson, S.J., Hall, J.W., Murgatroyd, A., Acreman, M., Bates, P., Beven, K., Heathwaite, L., Holden, J., Holman, I.P., Lane, S.N., O'connell, E., Penning-Rowsell, E., Reynard, N., Sear, D., Thorne, C., Wilby, R., 2017. A restatement of the natural science evidence concerning catchment-based "natural" flood management in the UK. Proc. R. Soc. A 473. https://doi.org/10.1098/rspa.2016.0706

Dang, Z., Liu, C., Haigh, M.J., 2002. Mobility of heavy metals associated with the natural weathering of coal mine spoils. Environ. Pollut. 118, 419-426. https://doi.org/10.1016/S02697491(01)00285-8 
Davranche, M., Grybos, M., Gruau, G., Pédrot, M., Dia, A., Marsac, R., 2011. Rare earth element patterns: A tool for identifying trace metal sources during wetland soil reduction. Chem. Geol. 284, 127-137. https://doi.org/10.1016/j.chemgeo.2011.02.014

Dawson, J.J.C., Tetzlaff, D., Carey, A.M., Raab, A., Soulsby, C., Killham, K., Meharg, A.A., 2010. Characterizing $\mathrm{Pb}$ mobilization from upland soils to streams using $206 \mathrm{~Pb} / 207 \mathrm{~Pb}$ isotopic ratios. Environ. Sci. Technol. 44, 243-249. https://doi.org/10.1021/es902664d

De Jonge, M., Teuchies, J., Meire, P., Blust, R., Bervoets, L., 2012. The impact of increased oxygen conditions on metal-contaminated sediments part I: Effects on redox status, sediment geochemistry and metal bioavailability. Water Res. 46, 2205-2214. https://doi.org/10.1016/J.WATRES.2012.01.052

de Souza Machado, A.A., Spencer, K., Kloas, W., Toffolon, M., Zarfl, C., 2016. Metal fate and effects in estuaries: A review and conceptual model for better understanding of toxicity. Sci. Total Environ. 541, 268-281. https://doi.org/10.1016/J.SCITOTENV.2015.09.045

de Souza Machado, A.A., Spencer, K.L., Zarfl, C., O’Shea, F.T., 2018. Unravelling metal mobility under complex contaminant signatures. Sci. Total Environ. 622-623, 373-384. https://doi.org/10.1016/J.SCITOTENV.2017.11.239

De Vivo, B., Belkin, H.E., Lima, A., 2008. Environmental Geochemistry: Site Characterization, Data Analysis And Case Histories, Environmental Geochemistry: Site Characterization, Data Analysis and Case Histories. Elsevier. https://doi.org/10.1016/B978-0-444-53159-9.X0001-0

Degryse, F., Smolders, E., Parker, D.R., 2009. Partitioning of metals ( $\mathrm{Cd}, \mathrm{Co}, \mathrm{Cu}, \mathrm{Ni}, \mathrm{Pb}, \mathrm{Zn}$ ) in soils: concepts, methodologies, prediction and applications - a review. Eur. J. Soil Sci. 60, 590-612. https://doi.org/10.1111/j.1365-2389.2009.01142.x

Domergue, F.L., Vedy, J.C., 1992. Mobility of heavy metals in soil profiles. Int. J. Environ. Anal. Chem. 46, 13-23. https://doi.org/10.1080/03067319208026993

Du Laing, G., Rinklebe, J., Vandecasteele, B., Meers, E., Tack, F.M.G., 2009. Trace metal behaviour in estuarine and riverine floodplain soils and sediments: A review. Sci. Total Environ. 407, 39723985. https://doi.org/10.1016/J.SCITOTENV.2008.07.025

Du Laing, G., Vanthuyne, D.R.J., Vandecasteele, B., Tack, F.M.G., Verloo, M.G., 2007. Influence of hydrological regime on pore water metal concentrations in a contaminated sediment-derived 
Eggleton, J., Thomas, K. V, 2004. A review of factors affecting the release and bioavailability of contaminants during sediment disturbance events. Environ. Int. 30, 973-980. https://doi.org/10.1016/J.ENVINT.2004.03.001

Ehlers, G.A.C., Loibner, A.P., 2006. Linking organic pollutant (bio)availability with geosorbent properties and biomimetic methodology: A review of geosorbent characterisation and (bio)availability prediction. Environ. Pollut. 141, 494-512. https://doi.org/10.1016/J.ENVPOL.2005.08.063

Ellis, J.B., Shutes, R.B.E., Revitt, M.D., 2003. Constructed Wetlands and Links with Sustainable Drainage Systems.

Emerson, Kodak U, Scholastica Bejor, E., Ekeng, E.E., Ogarekpe, Nkpa M, Emerson, K U, Bejor, E.S., Ogarekpe, N M, Onuruka, A.U., 2017. TRANSPORT AND FATE OF SELECTED HEAVY METALS IN CIRCUMNEUTRAL RIVER ENVIRONMENT: A CASE STUDY OF THE RIVER NENT CUMBRIA, ENGLAND. Int. J. Res. 5, 159-169. https://doi.org/10.5281/zenodo.818628

Euripidou, E., Murray, V., 2004. Public health impacts of floods and chemical contamination. J. Public Health (Bangkok). 26, 376-383. https://doi.org/10.1093/pubmed/fdh163

Evans, L.J., 1989. Chemistry of Metal Retention by Soils Chemistry of metal retention by soils Several processes are explained. Artic. Environ. Sci. Technol. https://doi.org/10.1021/es00067a001

Foley, J.A., DeFries, R., Asner, G.P., Barford, C., Bonan, G., Carpenter, S.R., Chapin, F.S., Coe, M.T., Daily, G.C., Gibbs, H.K., Helkowski, J.H., Holloway, T., Howard, E.A., Kucharik, C.J., Monfreda, C., Patz, J.A., Prentice, I.C., Ramankutty, N., Snyder, P.K., 2005. Global consequences of land use. Science (80-. ). https://doi.org/10.1126/science.1111772

Förstner, U., 2004. Traceability of sediment analysis. TrAC Trends Anal. Chem. 23, 217-236. https://doi.org/10.1016/S0165-9936(04)00312-7

Forstner, U., Wattman, G., 1981. Metal Pollution in the Aquatic Environment., 2nd ed. SpringerVerlag, Berlin.

Foulds, S.A., Griffiths, H.M., Macklin, M.G., Brewer, P.A., 2014. Geomorphological records of extreme floods and their relationship to decadal-scale climate change. Geomorphology 216, 193-207. https://doi.org/10.1016/J.GEOMORPH.2014.04.003 
Frohne, T., Diaz-Bone, R.A., Du Laing, G., Rinklebe, J., 2015. Impact of systematic change of redox potential on the leaching of $\mathrm{Ba}, \mathrm{Cr}, \mathrm{Sr}$, and $\mathrm{V}$ from a riverine soil into water. J. Soils Sediments 15, 623-633. https://doi.org/10.1007/s11368-014-1036-8

Frohne, T., Rinklebe, J., Diaz-Bone, R.A., 2014. Contamination of Floodplain Soils along the Wupper River, Germany, with $\mathrm{As}, \mathrm{Co}, \mathrm{Cu}, \mathrm{Ni}, \mathrm{Sb}$, and $\mathrm{Zn}$ and the Impact of Pre-definite Redox Variations on the Mobility of These Elements. Soil Sediment Contam. 23, 779-799. https://doi.org/10.1080/15320383.2014.872597

Frohne, T., Rinklebe, J., Diaz-Bone, R.A., Du Laing, G., 2011. Controlled variation of redox conditions in a floodplain soil: Impact on metal mobilization and biomethylation of arsenic and antimony. Geoderma 160, 414-424. https://doi.org/10.1016/J.GEODERMA.2010.10.012

Gadd, G.M., 2010. Metals, minerals and microbes: Geomicrobiology and bioremediation. Microbiology. https://doi.org/10.1099/mic.0.037143-0

Gall, Jillian E, Boyd, Robert S, Rajakaruna, Nishanta, Gall, J E, Rajakaruna, N, Boyd, R S, 2015. Transfer of heavy metals through terrestrial food webs: a review, Monitoring and Assessment.

Gambrell, R.P., 1994. Trace and Toxic Metals in Wetlands-A Review. J. Environ. Qual. 23, 883-891.

Gao, H., Shao, M., 2015. Effects of temperature changes on soil hydraulic properties. Soil Tillage Res. 153, 145-154. https://doi.org/10.1016/j.still.2015.05.003

Giacalone, A., Gianguzza, A., Orecchio, S., Piazzese, D., Dongarrà, G., Sciarrino, S., Varrica, D., 2005. Metals distribution in the organic and inorganic fractions of soil: A case study on soils from Sicily. Chem. Speciat. Bioavailab. 17, 83-93. https://doi.org/10.3184/095422905782774892

González-Alcaraz, M.N., van Gestel, C.A.M., 2015. Climate change effects on enchytraeid performance in metal-polluted soils explained from changes in metal bioavailability and bioaccumulation. Environ. Res. 142, 177-184. https://doi.org/10.1016/j.envres.2015.06.027

González-Macé, O., Steinauer, K., Jousset, A., Eisenhauer, N., Scheu, S., 2016. Flood-induced changes in soil microbial functions as modified by plant diversity. PLoS One 11. https://doi.org/10.1371/journal.pone.0166349

Gregory, A.S., Ritz, K., McGrath, S.P., Quinton, J.N., Goulding, K.W.T., Jones, R.J.A., Harris, J.A., Bol, R., Wallace, P., Pilgrim, E.S., Whitmore, A.P., 2015. A review of the impacts of degradation threats on soil properties in the UK. Soil Use Manag. 31, 1-15. 
1053

1054

1055

1056

1057

1058

1059

1060

1061

1062

1063

1064

1065

1066

1067

1068

1069

1070

1071

1072

1073

1074

1075

1076

1077

1078

1079

Grimm, A.M., Tedeschi, R.G., 2009. ENSO and extreme rainfall events in South America. J. Clim. 22, 1589-1609. https://doi.org/10.1175/2008JCLI2429.1

Gröngröft, A., Krüger, F., Grunewald, K., Meißner, R., Miehlich, G., 2005. Plant and soil contamination with trace metals in the Elbe floodplains: A case study after the flood in August 2002. Acta Hydrochim. Hydrobiol. 33, 466-474. https://doi.org/10.1002/aheh.200400596

Hahne, H.C.H., Kroontje, W., 1973. Significance of pH and Chloride Concentration on Behavior of Heavy Metal Pollutants: Mercury(II), Cadmium(II), Zinc(II), and Lead(II). J. Environ. Qual. 2, 444450. https://doi.org/10.2134/jeq1973.00472425000200040007x

Harvey, R.J., Chadwick, D.R., Sánchez-Rodríguez, A.R., Jones, D.L., 2019. Agroecosystem resilience in response to extreme winter flooding. Agric. Ecosyst. Environ. 279, 1-13. https://doi.org/10.1016/J.AGEE.2019.04.001

He, Y., Men, B., Yang, X., Li, Y., Xu, H., Wang, D., 2019. Relationship between heavy metals and dissolved organic matter released from sediment by bioturbation/bioirrigation. J. Environ. Sci. (China) 75, 216-223. https://doi.org/10.1016/j.jes.2018.03.031

Hillel, D., 1998. Introduction to Environmental Soil Physics, 1st ed. Academic Press.

Hippolyte, I., Jenny, C., Gardes L., Bakry F., Rivallan R., Pomies V., Cubry P., Tomekpe K., Risterucci A. M., Roux N., Rouard M., Arnaud E., Kolesnikova-Allen M., Perrier X., 2012. Foundation characteristics of edible Musa triploids revealed from allelic distribution of SSR markers. Ann. Bot. 109, 937-951. https://doi.org/10.1093/aob

Hirabayashi, Y., Kanae, S., 2009. First estimate of the future global population at risk of flooding. Hydrol. Res. Lett. 3, 6-9. https://doi.org/10.3178/hrl.3.6

Hirabayashi, Y., Kanae, S., Emori, S., Oki, T., Kimoto, M., 2008. Global projections of changing risks of floods and droughts in a changing climate. Hydrol. Sci. J. 53, 754-772. https://doi.org/10.1623/hysj.53.4.754

Hirabayashi, Y., Mahendran, R., Koirala, S., Konoshima, L., Yamazaki, D., Watanabe, S., Kim, H., Kanae, S., 2013. Global flood risk under climate change. Nat. Clim. Chang. 3, 816-821. https://doi.org/10.1038/nclimate1911 
Hobbelen, P.H.F., Koolhaas, J.E., van Gestel, C.A.M., 2006. Bioaccumulation of heavy metals in the earthworms Lumbricus rubellus and Aporrectodea caliginosa in relation to total and available metal concentrations in field soils. Environ. Pollut. 144, 639-646. https://doi.org/10.1016/J.ENVPOL.2006.01.019

Hooda, P.S., 2010. Trace Elements in Soils, Trace Elements in Soils. John Wiley and Sons. https://doi.org/10.1002/9781444319477

Huddart, D., Stott, T., Huddart, D., Stott, T., 2020. Climate Change and Adventure Tourism, in: Adventure Tourism. Springer International Publishing, pp. 437-469. https://doi.org/10.1007/978-3-030-18623-4_13

Hurley, R.R., Rothwell, J.J., Woodward, J.C., 2017. Metal contamination of bed sediments in the Irwell and Upper Mersey catchments, northwest England: exploring the legacy of industry and urban growth. J. Soils Sediments 17, 2648-2665. https://doi.org/10.1007/s11368-017-1668-6

Ibragimow, A., Walna, B., Siepak, M., 2013. Effects of Flooding on the Contamination of Floodplain Sediments with Available Fractions of Trace Metals (Western Poland), J. Environ. Stud.

IPCC, 2012. Managing the Risks of Extreme Events and Disasters to Advance Climate Change Adaptation. A Special Report of Working Groups I and II of the Intergovernmental Panel on Climate Change. [Field, C.B., V. Barros, T.F. Stocker, D. Qin, D.J. Dokken, K.L. Ebi, M.

Izquierdo, M., Tye, A.M., Chenery, S.R., 2017. Using isotope dilution assays to understand speciation changes in $\mathrm{Cd}, \mathrm{Zn}, \mathrm{Pb}$ and $\mathrm{Fe}$ in a soil model system under simulated flooding conditions. Geoderma 295, 41-52. https://doi.org/10.1016/J.GEODERMA.2017.02.006

Izquierdo, M., Tye, A.M., Chenery, S.R., 2013. Lability, solubility and speciation of $\mathrm{Cd}, \mathrm{Pb}$ and $\mathrm{Zn}$ in alluvial soils of the River Trent catchment UK. Environ. Sci. Process. Impacts 15, 1844-1858. https://doi.org/10.1039/c3em00370a

Jenkins, G.J., Murphy, J.M., Sexton, D.M.H., Lowe, J.A., Jones, P., Kilsby, C.G., 2009. UK Climate Projection Briefing Report [WWW Document]. Met Off. Hadley Cent. URL https://www.researchgate.net/publication/257343385_UK_Climate_Projection_Briefing_Repo rt (accessed 3.2.20).

Jiao, W., Ouyang, W., Hao, F., Huang, H., Shan, Y., Geng, X., 2014. Combine the soil water assessment tool (SWAT) with sediment geochemistry to evaluate diffuse heavy metal loadings at watershed 
Johnson, Z.F., Chikamoto, Y., Wang, S.Y.S., McPhaden, M.J., Mochizuki, T., 2020. Pacific decadal oscillation remotely forced by the equatorial Pacific and the Atlantic Oceans. Clim. Dyn. 55, 789-811. https://doi.org/10.1007/s00382-020-05295-2

Johnston, S.G., Burton, E.D., Aaso, T., Tuckerman, G., 2014. Sulfur, iron and carbon cycling following hydrological restoration of acidic freshwater wetlands. Chem. Geol. 371, 9-26. https://doi.org/10.1016/j.chemgeo.2014.02.001

Junk, W.J., Bayley, P.B., Sparks, R.E., 1989. The Flood Pulse Concept in River-Floodplain Systems. Can. Spec. Publ. Fish. Aquat. Sci. 106, 110-127. https://doi.org/10.1007/978-3-662-03416-3_4

Kalbitz, K., Wennrich, R., 1998. Mobilization of heavy metals and arsenic in polluted wetland soils and its dependence on dissolved organic matter. Sci. Total Environ. 209, 27-39. https://doi.org/10.1016/S0048-9697(97)00302-1

Karimian, N., Johnston, S.G., Burton, E.D., 2018. Iron and sulfur cycling in acid sulfate soil wetlands under dynamic redox conditions: A review. Chemosphere 197, 803-816. https://doi.org/10.1016/j.chemosphere.2018.01.096

Karimian, N., Johnston, S.G., Burton, E.D., 2017. Effect of cyclic redox oscillations on water quality in freshwater acid sulfate soil wetlands. Sci. Total Environ. https://doi.org/10.1016/j.scitotenv.2016.12.131

Karl, T.R., Trenberth, K.E., 2003. Modern Global Climate Change. Science (80-. ). 302, 1719-1723. https://doi.org/10.1126/science.1090228

Kelly, T.J., Hamilton, E., Watts, M.J., Ponting, J., Sizmur, T., 2020. The effect of flooding and drainage duration on the release of trace elements from floodplain soils. Environ. Toxicol. Chem. etc.4830. https://doi.org/10.1002/etc.4830

Kharin, V. V., Zwiers, F.W., Zhang, X., Hegerl, G.C., 2007. Changes in temperature and precipitation extremes in the IPCC ensemble of global coupled model simulations. J. Clim. 20, 1419-1444. https://doi.org/10.1175/JCLI4066.1

Kirk, G., 2004. The Biogeochemistry of Submerged Soils, The Biogeochemistry of Submerged Soils. Wiley \& Sons, Ltd: Chichester. https://doi.org/10.1002/047086303x 
Kiss, T.B.W., Chen, X., Ponting, J., Sizmur, T., Hodson, M.E., (In Review) Dual stresses of flooding and agricultural land use reduce earthworm populations more than the individual stressors. Sci. Total Environ. STOTEN-D-20-17138

Koretsky, C.M., Haveman, M., Beuving, L., Cuellar, A., Shattuck, T., Wagner, M., 2007. Spatial variation of redox and trace metal geochemistry in a minerotrophic fen. Biogeochemistry 86, 33-62. https://doi.org/10.1007/s10533-007-9143-x

Kowalik, C., Kraft, J., Einax, J.W., 2004. The situation of the German Elbe tributaries - Development of the loads in the last 10 years. Acta Hydrochim. Hydrobiol. 31, 334-345. https://doi.org/10.1002/aheh.200300507

Kulp, S.A., Strauss, B.H., 2019. New elevation data triple estimates of global vulnerability to sea-level rise and coastal flooding. Nat. Commun. 10,1-12. https://doi.org/10.1038/s41467-019-12808z

Kundzewicz, Z.W., Kanae, S., Seneviratne, S.I., Handmer, J., Nicholls, N., Peduzzi, P., Mechler, R., Bouwer, L.M., Arnell, N., Mach, K., Muir-Wood, R., Brakenridge, G.R., Kron, W., Benito, G., Honda, Y., Takahashi, K., Sherstyukov, B., 2014. Flood risk and climate change: global and regional perspectives. Hydrol. Sci. J. 59, 1-28. https://doi.org/10.1080/02626667.2013.857411

Lane, S.N., 2017. Natural flood management. Wiley Interdiscip. Rev. Water 4, e1211. https://doi.org/10.1002/wat2.1211

Le Gall, M., Ayrault, S., Evrard, O., Laceby, J.P., Gateuille, D., Lefèvre, I., Mouchel, J.-M., Meybeck, M., 2018. Investigating the metal contamination of sediment transported by the 2016 Seine River flood (Paris, France). Environ. Pollut. 240, 125-139. https://doi.org/10.1016/J.ENVPOL.2018.04.082

Lee, D.Y., Huang, J.C., Juang, K.W., Tsui, L., 2005. Assessment of phytotoxicity of chromium in flooded soils using embedded selective ion exchange resin method. Plant Soil 277, 97-105. https://doi.org/10.1007/s11104-005-5997-7

Lewin, J., Macklin, M.G., 2010. Floodplain catastrophes in the UK Holocene: Messages for managing climate change. Hydrol. Process. 24, 2900-2911. https://doi.org/10.1002/hyp.7704

Lloyd, J.R., 2003. Microbial reduction of metals and radionuclides. FEMS Microbiol. Rev. 27, 411425. https://doi.org/10.1016/S0168-6445(03)00044-5 
Lu, S., Ren, T., Gong, Y., Horton, R., 2007. An Improved Model for Predicting Soil Thermal Conductivity from Water Content at Room Temperature. Soil Sci. Soc. Am. J. 71, 8-14. https://doi.org/10.2136/sssaj2006.0041

Lučić, M., Jurina, I., Ščančar, J., Mikac, N., Vdović, N., 2019. Sedimentological and geochemical characterization of river suspended particulate matter (SPM) sampled by time-integrated mass flux sampler (TIMS) in the Sava River (Croatia). J. Soils Sediments 19, 989-1004. https://doi.org/10.1007/s11368-018-2104-2

Ma, M., Du, H., Wang, D., 2019. Mercury methylation by anaerobic microorganisms: A review. Crit. Rev. Environ. Sci. Technol. 49, 1893-1936. https://doi.org/10.1080/10643389.2019.1594517

Ma, R., McBratney, A., Whelan, B., Minasny, B., Short, M., 2011. Comparing temperature correction models for soil electrical conductivity measurement. Precis. Agric. https://doi.org/10.1007/s11119-009-9156-7

MacDonald, D., Dixon, A., Newell, A., Hallaways, A., 2012. Groundwater flooding within an urbanised flood plain. J. Flood Risk Manag. 5, 68-80. https://doi.org/10.1111/j.1753-318X.2011.01127.x

Macklin, M.G., Rumsby, B.T., 2007. Changing Climate and Extreme Floods in the British Uplands, New Series.

Madsen, H., Lawrence, D., Lang, M., Martinkova, M., Kjeldsen, T.R., 2014. Review of trend analysis and climate change projections of extreme precipitation and floods in Europe. J. Hydrol. 519, 3634-3650. https://doi.org/10.1016/J.JHYDROL.2014.11.003

Maggioni, V., Massari, C., 2018. On the performance of satellite precipitation products in riverine flood modeling: A review. J. Hydrol. 558, 214-224. https://doi.org/10.1016/J.JHYDROL.2018.01.039

Malmon, D. V., Dunne, T., Reneau, S.L., 2002. Predicting the Fate of Sediment and Pollutants in River Floodplains. Environ. Sci. Technol 36, 2026-2032. https://doi.org/10.1021/ES010509+

Malmon, D. V., Reneau, S.L., Dunne, T., 2004. Sediment sorting and transport by flash floods. J. Geophys. Res. Earth Surf. 109, n/a-n/a. https://doi.org/10.1029/2003jf000067

Maluckov, B.S., 2017. The Catalytic Role of Acidithiobacillus ferrooxidans for Metals Extraction from Mining - Metallurgical Resource. Biodivers. Int. J. 1. https://doi.org/10.15406/bij.2017.01.00017 
Martin, M., Bonifacio, E., Hossain, K.M.J., Huq, S.M.I., Barberis, E., 2014. Arsenic fixation and mobilization in the soils of the Ganges and Meghna floodplains. Impact of pedoenvironmental properties. Geoderma 228-229, 132-141. https://doi.org/10.1016/j.geoderma.2013.09.020

Meegoda, J.N., Martin, L., 2019. In-Situ Determination of Specific Surface Area of Clays. Geotech Geol Eng 37, 465-474. https://doi.org/https://doi.org/10.1007/s10706-018-0623-7

Mullan, D., Matthews, T., Vandaele, K., Barr, I.D., Swindles, G.T., Meneely, J., Boardman, J., Murphy, C., 2019. Climate impacts on soil erosion and muddy flooding at 1.5 versus $2^{\circ} \mathrm{C}$ warming. L. Degrad. Dev. 30, 94-108. https://doi.org/10.1002/ldr.3214

Naidu, R., Channey, R., McConnell, S., Johnston, N., Semple, K.T., McGrath, S., Dries, V., Nathanail, P., Harmsen, J., Pruszinski, A., MacMillan, J., Palanisami, T., 2015. Towards bioavailability-based soil criteria: past, present and future perspectives. Environ. Sci. Pollut. Res. 22, 8779-8785. https://doi.org/10.1007/s11356-013-1617-x

Naidu, R., Semple, K.T., Megharaj, M., Juhasz, A.L., Bolan, N.S., Gupta, S.K., Clothier, B.E., Schulin, R., 2008. Bioavailability: Definition, assessment and implications for risk assessment. Dev. Soil Sci. 32, 39-51. https://doi.org/10.1016/S0166-2481(07)32003-5

Neal, C., Smith, C.J., Jeffery, H.A., Jarvie, H.P., Robson, A.J., 1996. Trace element concentrations in the major rivers entering the Humber estuary, NE England. J. Hydrol. 182, 37-64. https://doi.org/10.1016/0022-1694(95)02940-0

Ng, J.C., Juhasz, A., Smith, E., Naidu, R., 2015. Assessing the bioavailability and bioaccessibility of metals and metalloids. Environ. Sci. Pollut. Res. 22, 8802-8825. https://doi.org/10.1007/s11356-013-1820-9

Niu, Z., Sun, L., Sun, T., Li, Y., Wang, H., 2007. Evaluation of phytoextracting cadmium and lead by sunflower, ricinus, alfalfa and mustard in hydroponic culture. J. Environ. Sci. 19, 961-967. https://doi.org/10.1016/S1001-0742(07)60158-2

Nouri, J., Khorasani, N., Lorestani, B., Karami, M., Hassani, A.H., Yousefi, N., 2009. Accumulation of heavy metals in soil and uptake by plant species with phytoremediation potential. Environ. Earth Sci. 59, 315-323. https://doi.org/10.1007/s12665-009-0028-2

Nriagu, J.O., Bhattacharya, P., Mukherjee, A.B., Bundschuh, J., Zevenhoven, R., Loeppert, R.H., 2007. Arsenic in soil and groundwater: an overview. Trace Met. other Contam. Environ. 9, 3-60. 
Nshimiyimana, F.X., Faciu, M.-E., Abidi, A. El, Blidi, S. El, Fekhaoui, M., Ifrim, I.L., Soulaymani, A., Lazar, G., 2014. ANALYSIS OF SEASONAL VARIATION ON DEGREE OF CONTAMINATION WITH HEAVY METALS IN AARJATE VILLAGE, MOROCCO. AN INDEX APPROACH. Sci. Study Res. Chem. Chem. Eng. Biotechnol. Food Ind. 15, 337-344.

Ostergren, J.D., Brown, G.E., Parks, G.A., Persson, P., 2000. Inorganic ligand effects on Pb(II) sorption to goethite ( $\alpha-\mathrm{FeOOH}$ ). II. Sulfate. J. Colloid Interface Sci. 225, 483-493. https://doi.org/10.1006/jcis.1999.6702

Overesch, M., Rinklebe, J., Broll, G., Neue, H.U., 2007. Metals and arsenic in soils and corresponding vegetation at Central Elbe river floodplains (Germany). Environ. Pollut. 145, 800-812. https://doi.org/10.1016/j.envpol.2006.05.016

Pan, L., Fang, G., Wang, Y., Wang, L., Su, B., Li, D., Xiang, B., 2018. Potentially toxic element pollution levels and risk assessment of soils and sediments in the upstream river, miyun reservoir, china. Int. J. Environ. Res. Public Health 15. https://doi.org/10.3390/ijerph15112364

Pappenberger, F., Dutra, E., Wetterhall, F., Cloke, H.L., 2012. Deriving global flood hazard maps of fluvial floods through a physical model cascade. Hydrol. Earth Syst. Sci. 16, 4143-4156. https://doi.org/10.5194/hess-16-4143-2012

Pathirana, A., Denekew, H.B., Veerbeek, W., Zevenbergen, C., Banda, A.T., 2014. Impact of urban growth-driven landuse change on microclimate and extreme precipitation - A sensitivity study. Atmos. Res. 138, 59-72. https://doi.org/10.1016/j.atmosres.2013.10.005

Peacock, M., Freeman, C., Gauci, V., Lebron, I., Evans, C.D., 2015. Investigations of freezing and cold storage for the analysis of peatland dissolved organic carbon (DOC) and absorbance properties. Environ. Sci. Process. Impacts 17, 1290-1301. https://doi.org/10.1039/c5em00126a

Peijnenburg, W.J.G.M., Zablotskaja, M., Vijver, M.G., 2007. Monitoring metals in terrestrial environments within a bioavailability framework and a focus on soil extraction. Ecotoxicol. Environ. Saf. 67, 163-179. https://doi.org/10.1016/J.ECOENV.2007.02.008

Pendergrass, A.G., 2018. What precipitation is extreme? Science (80-. ). 360, 1072-1073. https://doi.org/10.1126/science.aat1871

Plum, N.M., Filser, J., 2008. Worms and wetland water: the role of lumbricids and enchytraeids in 
nutrient mobilization from flooded soils, undefined.

1254

1255

1256

1257

1258

1259

1260

1261

1262

1263

1264

1265

1266

1267

1268

1269

1270

1271

1272

1273

1274

1275

1276

1277

1278

1279

1280

1281

Poot, A., Gillissen, F., Koelmans, A.A., 2007. Effects of flow regime and flooding on heavy metal availability in sediment and soil of a dynamic river system. Environ. Pollut. 148, 779-787. https://doi.org/10.1016/j.envpol.2007.01.045

Prudhomme, C., Davies, H., 2009. Assessing uncertainties in climate change impact analyses on the river flow regimes in the UK. Part 2: Future climate. Clim. Change 93, 197-222. https://doi.org/10.1007/s10584-008-9461-6

Prunty, L., Bell, J., 2005. Soil Temperature Change over Time during Infiltration. Soil Sci. Soc. Am. J. 69, 766-775. https://doi.org/10.2136/sssaj2004.0219

Puchalski, W., 2003. THE IMPORTANCE OF ACCUMULATED ORGANIC MATTERIN NUTRIENT TRANSPORT AND STORAGE IN FLOODPLAINS, in: International Conference "EcoFlood: Towards Natural Flood Reduction Strategies", Warsaw, EU Framework 5.

Pulchalski, W., 2003. The Importance of Accumulated Organic Matter in Nutrient Transport and Storage in Floodplains [WWW Document]. URL https://www.researchgate.net/publication/237333548_THE_IMPORTANCE_OF_ACCUMULATE D_ORGANIC_MATTERIN_NUTRIENT_TRANSPORT_AND_STORAGE_IN_FLOODPLAINS (accessed 2.24.20).

Pulley, S., Collins, A.L., 2019. Field-based determination of controls on runoff and fine sediment generation from lowland grazing livestock fields. J. Environ. Manage. 249, 109365. https://doi.org/10.1016/j.jenvman.2019.109365

Qiao, P., Lei, M., Yang, S., Yang, J., Zhou, X., Dong, N., Guo, G., 2019. Development of a model to simulate soil heavy metals lateral migration quantity based on SWAT in Huanjiang watershed, China. J. Environ. Sci. 77, 115-129. https://doi.org/10.1016/J.JES.2018.06.020

Rawlins, B.G., Wragg, J., Lark, R.M., 2013. Application of a novel method for soil aggregate stability measurement by laser granulometry with sonication. Eur. J. Soil Sci. 64, 92-103. https://doi.org/10.1111/ejss.12017

Rennert, T., Rabus, W., Rinklebe, J., 2017. Modelling the concentrations of dissolved contaminants $(\mathrm{Cd}, \mathrm{Cu}, \mathrm{Ni}, \mathrm{Pb}, \mathrm{Zn})$ in floodplain soils. Environ. Geochem. Health 39, 331-344. https://doi.org/10.1007/s10653-016-9859-4 
Resongles, E., Casiot, C., Freydier, R., Le Gall, M., Elbaz-Poulichet, F., 2015. Variation of dissolved and particulate metal(loid) ( $\mathrm{As}, \mathrm{Cd}, \mathrm{Pb}, \mathrm{Sb}, \mathrm{Tl}, \mathrm{Zn}$ ) concentrations under varying discharge during a Mediterranean flood in a former mining watershed, the Gardon River (France). J. Geochemical Explor. 158, 132-142. https://doi.org/10.1016/J.GEXPLO.2015.07.010

Rinklebe, J., Du Laing, G., 2011. Factors Controlling the Dynamics of Trace Metals in Frequently Flooded Soils, in: Dynamics and Bioavailability of Heavy Metals in the Rootzone. CRC Press, pp. 245-270. https://doi.org/10.1201/b10796-10

Rinklebe, J., During, A., Overesch, M., Du Laing, G., Wennrich, R., Stärk, H.J.H.J., Mothes, S., 2010. Dynamics of mercury fluxes and their controlling factors in large $\mathrm{Hg}$-polluted floodplain areas. Environ. Pollut. 158, 308-318. https://doi.org/10.1016/j.envpol.2009.07.001

Rinklebe, J., Franke, C., Neue, H.-U., 2007. Aggregation of floodplain soils based on classification principles to predict concentrations of nutrients and pollutants. Geoderma 141, 210-223. https://doi.org/10.1016/J.GEODERMA.2007.06.001

Rinklebe, J., Knox, A.S., Paller, M., Knox, A.S., Paller, M., 2016. Potential Mobility, Bioavailability, and Plant Uptake of Toxic Elements in Temporary Flooded Soils In book: Trace elements in waterlogged soils and sediments, 1st ed. CRC Press, Taylor \& Francis Group, New York. https://doi.org/10.1201/9781315372952-23

Rinklebe, J., Shaheen, S.M., 2017. Redox chemistry of nickel in soils and sediments: A review. Chemosphere 179, 265-278. https://doi.org/10.1016/J.CHEMOSPHERE.2017.02.153

Rinklebe, J., Wennrich, R., Du Laing, G., Stark, H.J., Mothes, S., 2013. Mercury emissions from flooded soils and sediments in Germany are an underestimated problem: challenges for reliable risk assessments and management strategies. E3S Web Conf. 1.

Rizzo, A., Bresciani, R., Masi, F., Boano, F., Revelli, R., Ridolfi, L., 2018. Flood reduction as an ecosystem service of constructed wetlands for combined sewer overflow. J. Hydrol. 560, 150159. https://doi.org/10.1016/j.jhydrol.2018.03.020

Rodgers, K., Hursthouse, A., Cuthbert, S., 2015. The Potential of Sequential Extraction in the Characterisation and Management of Wastes from Steel Processing: A Prospective Review. Int. J. Environ. Res. Public Health 12, 11724-11755. https://doi.org/10.3390/ijerph120911724 
sediments transferred by a catastrophic flood and related changes in groundwater quality. J. Hydrol. 369, 326-335. https://doi.org/10.1016/J.JHYDROL.2009.02.023

Sánchez-Rodríguez, A.R., Nie, C., Hill, P.W., Chadwick, D.R., Jones, D.L., 2019. Extreme flood events at higher temperatures exacerbate the loss of soil functionality and trace gas emissions in grassland. Soil Biol. Biochem. 130, 227-236. https://doi.org/10.1016/J.SOILBIO.2018.12.021

Schaller, N., Kay, A.L., Lamb, R., Massey, N.R., Van Oldenborgh, G.J., Otto, F.E.L., Sparrow, S.N., Vautard, R., Yiou, P., Ashpole, I., Bowery, A., Crooks, S.M., Haustein, K., Huntingford, C., Ingram, W.J., Jones, R.G., Legg, T., Miller, J., Skeggs, J., Wallom, D., Weisheimer, A., Wilson, S., Stott, P.A., Allen, M.R., 2016. Human influence on climate in the 2014 southern England winter floods and their impacts. Nat. Clim. Chang. 6, 627-634. https://doi.org/10.1038/nclimate2927

Schulz-Zunkel, C., Krueger, F., 2009. Trace Metal Dynamics in Floodplain Soils of the River Elbe: A Review. J. Environ. Qual. 38, 1349-1362. https://doi.org/10.2134/jeq2008.0299

Schulz-Zunkel, C., Rinklebe, J., Bork, H.-R., 2015. Trace element release patterns from three floodplain soils under simulated oxidized-reduced cycles. Ecol. Eng. 83, 485-495. https://doi.org/10.1016/J.ECOLENG.2015.05.028

Selinus, O., Alloway, B., Centeno, J.A., Robert B. Finkelman, Fuge, R., Lindh, U., Smedley, P., 2005. Essentials of Medical Geology: Impacts of the Natural Environment on Public Health. Elsevier Academic Press.

Shaheen, S.M., Frohne, T., White, J.R., DeLaune, R.D., 2017. Redox-induced mobilization of copper, selenium, and zinc in deltaic soils originating from Mississippi (U.S.A.) and Nile (Egypt) River Deltas: A better understanding of biogeochemical processes for safe environmental management. J. Environ. Manage. 186, 131-140. https://doi.org/10.1016/J.JENVMAN.2016.05.032

Shaheen, S.M., Rinklebe, J., 2017. Sugar beet factory lime affects the mobilization of Cd, Co, Cr, Cu, $\mathrm{Mo}, \mathrm{Ni}, \mathrm{Pb}$, and $\mathrm{Zn}$ under dynamic redox conditions in a contaminated floodplain soil. J. Environ. Manage. 186, 253-260. https://doi.org/10.1016/j.jenvman.2016.07.060

Shaheen, S.M., Rinklebe, J., 2014. Geochemical fractions of chromium, copper, and zinc and their vertical distribution in floodplain soil profiles along the Central Elbe River, Germany. Geoderma 228-229, 142-159. https://doi.org/10.1016/J.GEODERMA.2013.10.012 
Shaheen, S.M., Rinklebe, J., Frohne, T., White, J.R., DeLaune, R.D., 2016. Redox effects on release kinetics of arsenic, cadmium, cobalt, and vanadium in Wax Lake Deltaic freshwater marsh soils. Chemosphere 150, 740-748. https://doi.org/10.1016/J.CHEMOSPHERE.2015.12.043

Shaheen, S.M., Rinklebe, J., Rupp, H., Meissner, R., 2014a. Temporal dynamics of pore water concentrations of $\mathrm{Cd}, \mathrm{Co}, \mathrm{Cu}, \mathrm{Ni}$, and $\mathrm{Zn}$ and their controlling factors in a contaminated floodplain soil assessed by undisturbed groundwater lysimeters. Environ. Pollut. 191, 223-231. https://doi.org/10.1016/J.ENVPOL.2014.04.035

Shaheen, S.M., Rinklebe, J., Rupp, H., Meissner, R., 2014b. Lysimeter trials to assess the impact of different flood-dry-cycles on the dynamics of pore water concentrations of $\mathrm{As}, \mathrm{Cr}$, Mo and V in a contaminated floodplain soil. Geoderma 228-229, 5-13. https://doi.org/10.1016/J.GEODERMA.2013.12.030

Shahid, M., Shamshad, S., Rafiq, M., Khalid, S., Bibi, I., Niazi, N.K., Dumat, C., Rashid, M.I., 2017. Chromium speciation, bioavailability, uptake, toxicity and detoxification in soil-plant system: A review. Chemosphere 178, 513-533. https://doi.org/10.1016/J.CHEMOSPHERE.2017.03.074

Sherene, T., 2010. Mobility and Transport of Heavy Metals in Polluted Soil Environment. Biol. Forum-An Int. J. 2, 112-121.

Simmler, M., Bommer, J., Frischknecht, S., Christl, I., Kotsev, T., Kretzschmar, R., 2017. Reductive solubilization of arsenic in a mining-impacted river floodplain: Influence of soil properties and temperature. Environ. Pollut. 231, 722-731. https://doi.org/10.1016/J.ENVPOL.2017.08.054

Sipos, P., Choi, C., Németh, T., Szalai, Z., Póka, T., 2014. Relationship between iron and trace metal fractionation in soils. Chem. Speciat. Bioavailab. 26, 21-30. https://doi.org/10.3184/095422914X13887685052506

Sivakumar, S., Subbhuraam, C.V., 2005. Toxicity of chromium(III) and chromium(VI) to the earthworm Eisenia fetida. Ecotoxicol. Environ. Saf. 62, 93-98. https://doi.org/10.1016/J.ECOENV.2004.08.006

Sizmur, T., Hodson, M.E., 2009. Do earthworms impact metal mobility and availability in soil? - A review. Environ. Pollut. 157, 1981-1989. https://doi.org/10.1016/J.ENVPOL.2009.02.029

Sizmur, T., Palumbo-Roe, B., Watts, M.J., Hodson, M.E., 2011. Impact of the earthworm Lumbricus terrestris (L.) on $\mathrm{As}, \mathrm{Cu}, \mathrm{Pb}$ and $\mathrm{Zn}$ mobility and speciation in contaminated soils. Environ. 
Sizmur, T., Richardson, J., 2020. Earthworms accelerate the biogeochemical cycling of potentially toxic elements: Results of a meta-analysis. Soil Biol. Biochem. 148, 107865. https://doi.org/10.1016/j.soilbio.2020.107865

Spurgeon, D.J., Hopkin, S.P., 1999. Comparisons of metal accumulation and excretion kinetics in earthworms (Eisenia fetida) exposed to contaminated ${ }^{\circledR}$ eld and laboratory soils. Appl. Soil Ecol. $11,227-243$

Srivastava, V., Sarkar, A., Singh, S.K., Singh, P.K., De Araujo, A.S.F., Singh, R.P., 2017. Agroecological Responses of Heavy Metal Pollution with Special Emphasis on Soil Health and Plant Performances. Front. Environ. Sci 5, 64. https://doi.org/10.3389/fenvs.2017.00064

Stafford, A., Jeyakumar, P., Hedley, M., Anderson, C., 2018. Influence of Soil Moisture Status on Soil Cadmium Phytoavailability and Accumulation in Plantain (Plantago lanceolata). Soil Syst. 2, 9. https://doi.org/10.3390/soils2010009

Stagl, J., Mayr, E., Koch, H., Hattermann, F.F., Huang, S., 2014. Effects of Climate Change on the Hydrological Cycle in Central and Eastern Europe, in: Advances in Global Change Research. Springer International Publishing, pp. 31-43. https://doi.org/10.1007/978-94-007-7960-0_3

Stahl, R.G., Hooper, M.J., Balbus, J.M., Clements, W., Fritz, A., Gouin, T., Helm, R., Hickey, C., Landis, W., Moe, S.J., 2013. The influence of global climate change on the scientific foundations and applications of Environmental Toxicology and Chemistry: Introduction to a SETAC international workshop. Environ. Toxicol. Chem. 32, 13-19. https://doi.org/10.1002/etc.2037

Steinnes, E., 2013. Heavy metal contamination of the terrestrial environment from long-range atmospheric transport: Evidence from 35 years of research in Norway. E3S Web Conf. 1, 35001. https://doi.org/10.1051/E3SCONF/20130135001

Stuart, M.., Lapworth, D.., 2011. A review of processes important in the floodplain setting. Br. Geol. Surv. $32(\mathrm{OR} / 11 / 030)$.

Stürck, J., Poortinga, A., Verburg, P.H., 2014. Mapping ecosystem services: The supply and demand of flood regulation services in Europe. Ecol. Indic. 38, 198-211. https://doi.org/10.1016/j.ecolind.2013.11.010 
Tack, F.M., Verloo, M.G., 1995. Chemical Speciation and Fractionation in Soil and Sediment Heavy Metal Analysis: A Review, Chemical. International Journal of Environmental Analytical Chemistry.

Tack, F.M.G., 2010. Trace elements: General soil chemistry, principles and processes, in: Trace Elements in Soils. John Wiley and Sons, pp. 9-37. https://doi.org/10.1002/9781444319477.ch2

Tack, F.M.G., Van Ranst, E., Lievens, C., Vandenberghe, R.E., 2006. Soil solution Cd, Cu and Zn concentrations as affected by short-time drying or wetting: The role of hydrous oxides of Fe and Mn. Geoderma 137, 83-89. https://doi.org/10.1016/j.geoderma.2006.07.003

Tedeschi, R.G., Collins, M., 2016. The influence of ENSO on South American precipitation during austral summer and autumn in observations and models. Int. J. Climatol. 36, 618-635. https://doi.org/10.1002/joc.4371

Thapa, R., Thoms, M.C., Parsons, M., Reid, M., 2016. Adaptive cycles of floodplain vegetation response to flooding and drying. Earth Surf. Dyn. 4, 175-191. https://doi.org/10.5194/esurf-4$175-2016$

Thomas, S.K., Severson, E.D., Galbraith, J.M., 2016. Measuring Saturated Hydraulic Conductivity in Soil. Virginia Coop. Extension, Blacksburg, VA. 1-13.

Tockner, K., Lorang, M.S., Stanford, J.A., 2010. River flood plains are model ecosystems to test general hydrogeomorphic and ecological concepts. River Res. Appl. 26, 76-86. https://doi.org/10.1002/rra.1328

Tockner, K., Stanford, J.A., 2002. Riverine flood plains: Present state and future trends. Environ. Conserv. 29, 308-330. https://doi.org/10.1017/\$037689290200022X

Tóth, G., Hermann, T., Da Silva, M.R., Montanarella, L., 2016a. Heavy metals in agricultural soils of the European Union with implications for food safety. Environ. Int. 88, 299-309. https://doi.org/10.1016/J.ENVINT.2015.12.017

Tóth, G., Hermann, T., Szatmári, G., Pásztor, L., 2016b. Maps of heavy metals in the soils of the European Union and proposed priority areas for detailed assessment. Sci. Total Environ. 565, 1054-1062. https://doi.org/10.1016/J.SCITOTENV.2016.05.115 
Unger, I.M., Kennedy, A.C., Muzika, R.-M., 2009. Flooding effects on soil microbial communities. Appl. Soil Ecol. 42, 1-8. https://doi.org/10.1016/J.APSOIL.2009.01.007

Vaughan, K.L., Rabenhorst, M.C., Needelman, B.A., 2009. Saturation and Temperature Effects on the Development of Reducing Conditions in Soils. Soil Sci. Soc. Am. J. 73, 663-667. https://doi.org/10.2136/sssaj2007.0346

Vijver, M.G., Vink, J.P.M., Miermans, C.J.H., van Gestel, C.A.M., 2007. Metal accumulation in earthworms inhabiting floodplain soils. Environ. Pollut. 148, 132-140. https://doi.org/10.1016/j.envpol.2006.10.046

Vink, J.P.M., Meeussen, J.C.L., 2007. BIOCHEM-ORCHESTRA: A tool for evaluating chemical speciation and ecotoxicological impacts of heavy metals on river flood plain systems. Environ. Pollut. 148, 833-841. https://doi.org/10.1016/J.ENVPOL.2007.01.041

Violante, A., 2013. Elucidating Mechanisms of Competitive Sorption at the Mineral/Water Interface. Adv. Agron. 118, 111-176. https://doi.org/10.1016/B978-0-12-405942-9.00003-7

Violante, A., Cozzolino, V., Perelomov, L., Caporale, A.G., Pigna, M., 2010. Mobility and bioavailability of heavy metals and metalloids in soil environments. J. Soil Sci. Plant Nutr. 10, 268-292. https://doi.org/10.4067/S0718-95162010000100005

Visser, A., Kroes, J., Van Vliet, M.T.H., Blenkinsop, S., Fowler, H.J., Broers, H.P., 2012. Climate change impacts on the leaching of a heavy metal contamination in a small lowland catchment, in: Journal of Contaminant Hydrology. Elsevier, pp. 47-64. https://doi.org/10.1016/j.jconhyd.2011.04.007

Weber, F.-A., Voegelin, A., Kretzschmar, R., 2009. Multi-metal contaminant dynamics in temporarily flooded soil under sulfate limitation. Geochim. Cosmochim. Acta 73, 5513-5527. https://doi.org/10.1016/J.GCA.2009.06.011

Wheater, H., Evans, E., 2009. Land use, water management and future flood risk. Land use policy 26, S251-S264. https://doi.org/10.1016/J.LANDUSEPOL.2009.08.019

Wijngaard, R.R., van der Perk, M., van der Grift, B., de Nijs, T.C.M., Bierkens, M.F.P., 2017. The Impact of Climate Change on Metal Transport in a Lowland Catchment. Water. Air. Soil Pollut. 228, 107. https://doi.org/10.1007/s11270-017-3261-4

Wilby, R.L., Beven, K.J., Reynard, N.S., 2008. Climate change and fluvial flood risk in the UK: more of 
Winger, P.V. V, Lasier, P.J.J., Jackson, B.P.P., 1998. The Influence of Extraction Procedure on Ion Concentrations in Sediment Pore Water. Arch. Environ. Contam. Toxicol. 35, 8-13. https://doi.org/10.1007/s002449900341

Wright, A.J., de Kroon, H., Visser, E.J.W., Buchmann, T., Ebeling, A., Eisenhauer, N., Fischer, C., Hildebrandt, A., Ravenek, J., Roscher, C., Weigelt, A., Weisser, W., Voesenek, L.A.C.J., Mommer, L., 2017. Plants are less negatively affected by flooding when growing in species-rich plant communities. New Phytol. 213, 645-656. https://doi.org/10.1111/nph.14185

Wuana, R.A., Okieimen, F.E., Montuelle, B., Steinman, A.D., 2011. Heavy Metals in Contaminated Soils: A Review of Sources, Chemistry, Risks and Best Available Strategies for Remediation. Int. Sch. Res. Netw. ISRN Ecol. 2011, 20. https://doi.org/10.5402/2011/402647

Wyszkowska, J., Borowik, A., Kucharski, M., Kucharski, J., 2013. Effect of cadmium, copper and zinc on plants, soil microorganisms and soil enzymes. J. Elem. https://doi.org/10.5601/jelem.2013.18.4.455

Xu, J., Zheng, L., Xu, L., Wang, X., 2020. Uptake and allocation of selected metals by dominant vegetation in Poyang Lake wetland: From rhizosphere to plant tissues. Catena 189, 104477. https://doi.org/10.1016/j.catena.2020.104477

Xu, J.M., Tang, C., Chen, Z.L., 2006. The role of plant residues in $\mathrm{pH}$ change of acid soils differing in initial pH. Soil Biol. Biochem. 38, 709-719. https://doi.org/10.1016/j.soilbio.2005.06.022

Xu, Y., Feng, L., Jeffrey, P.D., Shi, Y., Morel, F.M.M., 2008. Structure and metal exchange in the cadmium carbonic anhydrase of marine diatoms. Nature 452, 56-61. https://doi.org/10.1038/nature06636

Yang, C., Li, S., Liu, R., Sun, P., Liu, K., 2015. Effect of reductive dissolution of iron (hydr)oxides on arsenic behavior in a water-sediment system: First release, then adsorption. Ecol. Eng. 83, 176183. https://doi.org/10.1016/j.ecoleng.2015.06.018

Zhao, Y., Marriott, S., Rogers, J., Iwugo, K., 1999. A preliminary study of heavy metal distribution on the floodplain of the River Severn, UK by a single flood event. Sci. Total Environ. 243-244, 219231. https://doi.org/10.1016/S0048-9697(99)00386-1 
1484

1485

1486

1487

1488

1489

1490

1491

1492

1493

System, UK. Procedia Environ. Sci. 18, 167-173.

https://doi.org/10.1016/J.PROENV.2013.04.022

Zia, A., van den Berg, L., Ahmad, M.N., Riaz, M., Zia, D., Ashmore, M., 2018. Controls on accumulation and soil solution partitioning of heavy metals across upland sites in United Kingdom (UK). J. Environ. Manage. 222, 260-267. https://doi.org/10.1016/J.JENVMAN.2018.05.076 